\title{
The thermo-sensitive gene expression signatures of spermatogenesis
}

\author{
Santosh K. Yadav ${ }^{1 \dagger}$, Aastha Pandey ${ }^{1 \dagger}$, Lokesh Kumar ${ }^{1}$, Archana Devi $^{1,2}$, Bhavana Kushwaha $^{1,2}$, Rahul Vishvkarma ${ }^{1}$, \\ Jagdamba P. Maikhuri', Singh Rajender ${ }^{1,2}$ and Gopal Gupta ${ }^{1,2^{*}}$
}

\begin{abstract}
Background: Spermatogenesis in most mammals (including human and rat) occurs at $\sim 3^{\circ} \mathrm{C}$ lower than body temperature in a scrotum and fails rapidly at $37^{\circ} \mathrm{C}$ inside the abdomen. The present study investigates the heat-sensitive transcriptome and miRNAs in the most vulnerable germ cells (spermatocytes and round spermatids) that are primarily targeted at elevated temperature in a bid to identify novel targets for contraception and/or infertility treatment.
\end{abstract}

Methods: Testes of adult male rats subjected to surgical cryptorchidism were obtained at 0, 24, 72 and $120 \mathrm{~h}$ post-surgery, followed by isolation of primary spermatocytes and round spermatids and purification to $>90 \%$ purity using a combination of trypsin digestion, centrifugal elutriation and density gradient centrifugation techniques. RNA isolated from these cells was sequenced by massive parallel sequencing technique to identify the most-heat sensitive mRNAs and miRNAs.

Results: Heat stress altered the expression of a large number of genes by $\geq 2.0$ fold, out of which 594 genes $(286 \uparrow ; 308 \downarrow)$ showed alterations in spermatocytes and 154 genes $(105 \uparrow ; 49 \downarrow)$ showed alterations in spermatids throughout the duration of experiment. 62 heat-sensitive genes were common to both cell types. Similarly, 66 and 60 heat-sensitive miRNAs in spermatocytes and spermatids, respectively, were affected by $\geq 1.5$ fold, out of which 6 were common to both the cell types. Conclusion: The study has identified Acly, selV, SLC16A7(MCT-2), Txnrd1 and Prkar2B as potential heat sensitive targets in germ cells, which may be tightly regulated by heat sensitive miRNAs rno-miR-22-3P, rno-miR-22-5P, rno-miR-129-5P, rno-miR-3560, rno-miR-3560 and rno-miR-466c-5P.

\section{Background}

In most mammals, normal spermatogenesis occurs in a scrotum at a temperature lower than body $\left(\sim 3^{\circ} \mathrm{C}\right)$, but fails rapidly inside the abdomen at body temperature. In contrast to other developmental and biological processes, which occur normally at body temperature $\left(\sim 37{ }^{\circ} \mathrm{C}\right)$, spermatogenesis completely ceases at this temperature. The scrotum is nature's uniquely designed organ to maintain testes at $\sim 3{ }^{\circ} \mathrm{C}$ lower than the body-temperature. Limited clinical studies have reported that transient testicular heating of adult human males results in reversible spermatogenic arrest, and hence could be used as a method of contraception [1]. However, the practical-feasibility of physically heating the testis by thermal insulators and/or

\footnotetext{
* Correspondence: g_gupta@cdri.res.in

${ }^{\dagger}$ Santosh K. Yadav and Aastha Pandey contributed equally to this work.

'Division of Endocrinology, CSIR-Central Drug Research Institute, BS-10/1,

Sector-10, Jankipuram Extension, Sitapur Road, Lucknow 226031, India

${ }^{2}$ Academy of Scientific and Innovative Research (AcSIR), New Delhi 110001, India
}

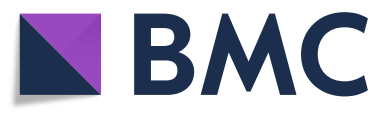

(0) The Author(s). 2018 Open Access This article is distributed under the terms of the Creative Commons Attribution 4.0 International License (http://creativecommons.org/licenses/by/4.0/), which permits unrestricted use, distribution, and

reproduction in any medium, provided you give appropriate credit to the original author(s) and the source, provide a link to the Creative Commons license, and indicate if changes were made. The Creative Commons Public Domain Dedication waiver (http://creativecommons.org/publicdomain/zero/1.0/) applies to the data made available in this article, unless otherwise stated. clinical application as a method of contraception.

Cryptorchidism (undescended testes) is a condition in which the testes fail to descend into the scrotum and remain in abdomen due to developmental defects. It is one of the most common congenital abnormalities observed in 1$5 \%$ of full-term male births and is a risk factor for infertility [3]. It has been well documented that meiotic (pachytene/ diplotene spermatocytes) and post-meiotic (round spermatids) are the most heat sensitive germ cell types that undergo quick apoptosis under heat-stress/cryptorchidism in men [4] and rats [5, 6]. The higher sensitivity of germ cells to mild heat stress in comparison to the somatic cells (e.g. Sertoli and Leydig cells) could apparently be due to their high proliferative activity [7], making it an attractive target for contraceptive intervention.

The spermatogenesis is regulated at transcriptional, post-transcriptional and epigenetic levels by integrated expressions of an array of testicular genes in a precise temporal fashion $[8,9]$. In recent years, several high 
throughput differential gene expression studies on spermatogenesis have been performed in rodents, mostly using microarray technology, either in whole testes of prepubertal animals [10-12] or elutriation/Staput-enriched primary spermatocytes and round spermatids [13-15]. Though microarray technique has been employed as a potential tool to identify candidate genes playing important roles in fertility [16, 17], it is limited by its application to known transcripts, and does not contemplate testicular peculiarities such as the remarkable number of splice variants that are differentially expressed in spermatogenic cells $[18,19]$. Recently, massive parallel sequencing has been applied successfully to undertake gene expression analysis because of its better sensitivity and capability to identify and quantify novel transcribed regions and splice variants [20-22]. Most recently, da Cruz et al. [23] employed this technology to analyze meiotic and post-meiotic gene expression signatures of mouse transcriptome. However, the thermo-sensitive transcriptome of germ cells reflecting early degenerative changes in these cells have not been explored. In addition to improving our understanding of molecular regulation of spermatogenesis, identification of thermo-sensitive genes could be exploited to achieve contraception by 'molecular heating' in testis instead of actual physical heating. The present study investigates the changes in transcriptome profile of spermatocytes and spermatids from rat testes subjected to surgical cryptorchidism to identify the most heat-sensitive genes in testes.

\section{Methods}

\section{Animals}

The Institutional Animal Ethics Committee of CDRI, Lucknow, approved the study. Adult male Sprague-Dawley (SD) rats, aged 14 to 16 weeks and weighing $220-250$ g, maintained in institute's air conditioned $\left(24 \pm 1^{\circ} \mathrm{C}\right)$ quarters with constant photoperiod of $12 \mathrm{~h}$ light and $12 \mathrm{~h}$ dark and free access to the standard pellet diet and water ad libitum, were used in these investigations.

\section{Surgical cryptorchidism}

Rats were anesthetized with ketamine $(50 \mathrm{mg} / \mathrm{kg})$ and xylazine $(10 \mathrm{mg} / \mathrm{kg})$, and bilateral cryptorchidism was induced surgically through the abdominal route by anchoring both the testes to the inner lateral abdominal wall using a suture passing through the connective tissue of the cauda epididymis. The animals were autopsied 24, 72 and $120 \mathrm{~h}$ after the surgery and the testes were removed. One testis from each animal of every group was fixed in $10 \%$ formalin for histological studies while the other testis was used for isolation of germ cells. Each group consisted of 5 animals and sham-operated rats served as controls.

\section{Hematoxylin and eosin (H\&E) and TUNEL assay}

Testes tissues fixed in $10 \%$ buffered formalin were embedded in paraffin and $5 \mu$ sections were cut using a microtome (Leica Biosystems, Nussloch, Germany). Sections were processed for $\mathrm{H} \& \mathrm{E}$ staining and thereafter analyzed under a light microscope (Nikon) and their images were captured using NIS elements software, at suitable magnification. Tunel assay was performed using paraffin embedded tissue sections by following the instructions provided with Promega Tunel assay kit (cat no. G3250). Briefly, the paraffin embedded tissue sections were deparaffinised, rehydrated in a series of ethanol, fixed with $4 \%$ paraformaldehyde, treated with proteinase- $\mathrm{K}$ solution followed by treatment with equilibrating buffer and rTDT incubation buffer for $1 \mathrm{~h}$. Finally the tissues were washed counterstained with DAPI and stored at $4{ }^{\circ} \mathrm{C}$. Thereafter tissue sections were analysed under flourescence microscope (Nikon) and the images were captured using NIS elements software, at suitable magnification. For statistical analysis of the number of primary spermatocytes and round spermatids present in sham (control), 24, 72 and $120 \mathrm{~h}$ of cryptorchid testes, the same were counted in three different areas of three different sections from each group, and the data has been analysed by one-way analysis of variance (ANOVA). $P$ values less than 0.05 were considered as significant.

\section{Isolation and purification of spermatocytes and round spermatids from rat testis}

Primary spermatocytes and round spermatids were isolated by trypsin digestion and purified by centrifugal elutriation and density gradient centrifugation by the method of Meistrich et al. [24]. Briefly, the testes were decapsulated and minced with scissors in Basal Medium Eagle (BME). Subsequently, the minced suspension was incubated for 15 min with shaking in a water bath at $34{ }^{\circ} \mathrm{C}$ in Basal Medium Eagle (BME) supplemented with $0.1 \%$ trypsin $(w / v), 0.1 \%$ glucose and $17 \mu \mathrm{g} / \mathrm{ml}$ DNase. After incubation, the enzyme reaction was stopped by addition of Soybean trypsin inhibitor $(0.04 \% \mathrm{w} / \mathrm{v})$, and the cell-suspension was filtered through a nylon mesh $(36 \mu \mathrm{m})$ and passed through a column of glass wool to remove sperm. The ensued cell suspension was centrifuged at $400 \mathrm{~g}$ for $5 \mathrm{~min}$ at $4{ }^{\circ} \mathrm{C}$ and the cell pellet obtained was washed twice with BME. The mixed germ cell population was suspended in BME containing DNase $(2 \mu \mathrm{g} / \mathrm{ml})$ and FBS $(8 \% V / \mathrm{V})$ and kept on ice. Later, the cell suspension was elutriated with a Beckman Elutriator Rotor (JE-5) fitted with a standard chamber and mounted on a Beckman High Speed Centrifuge (Avanti J-26S-XP). Two fractions (I and II) were collected at $3000 \mathrm{rpm}$ at flow rates of 18.0 and $31.5 \mathrm{ml} /$ $\mathrm{min}$, and then the rotor speed was reduced to $2000 \mathrm{rpm}$ and another two fractions (III and IV) were collected at 
flow rates of 23.0 and $40.0 \mathrm{ml} / \mathrm{min}$, respectively. Fractions II and IV contained pachytene spermatocytes and round spermatids at purities of $\sim 80 \%$ and $\sim 75 \%$, respectively. The fractions II and IV were layered separately over linear Percoll gradients of $25-37 \%$ and $23-$ $33 \%$ Percoll, respectively, and centrifuged at $4025 \mathrm{~g}$ for $60 \mathrm{~min}$ in a swinging bucket rotor fitted on to a Sigma 3-30 K refrigerated centrifuge. The major band was recovered through a puncture in the side of the tube, washed and diluted with BME. Further, the purity of isolated cells was checked visually under a microscope and through DNA quantitation using flow cytometry.

\section{RNA isolation and sequencing}

A Qiagen RNeasy Micro Kit (74,004, Qiagen) was used to extract RNA from the sorted cells. The extraction was performed according to Quick-Start Protocol suggested by the manufacturers. miRNA was isolated from the total RNA population by the ligation of a 3' RNA adapter using t4 RNA ligase and ligation buffer. The 3'adapter ligated small RNA was again 5' ligated with 5'RNA adapter and then the corresponding small RNA was reverse transcribed and amplified to generate cDNA constructs. These cDNA constructs were purified using 6\% PAGE and the corresponding small RNA bands were excised between 140 and 160 bp lengths. The cDNA construct from the gel was recovered by filtration and subsequently precipitated with ethanol. These were quantified and subjected to sequencing and data analysis. The integrity and quality of the extracted RNAs were checked by Agilent 2100 bioanalyzer and the qualified RNA samples were used for sequencing. A total of 3 pools were prepared for each type of cells to have three biological replicates. Dynabeads mRNA DIRECTTM kit (610.12, Life Technologies) was used to enrich RNAs with polyA tail. mRNA-seq library was prepared using TruSeq RNA kit (RS-122-2001, Illumina). Sequencing was performed on Illumina Hiseq 2500 next generation sequencing platform. Sequencing-v3 (634,848, Clontech Laboratories) was used to amplify the cDNA derived from these cells before sequencing was performed.

\section{Raw data production and preprocessing}

TopHat (v2.0.8b, http://tophat.cbcb.umd.edu/) was used to map the RNA-seq reads to rat genome build hg19 (UCSC). The reads with low quality were removed from the raw sequencing reads. Read mapping were performed using Tophat ( $\mathrm{R}$ software), reads count were obtained using HTSeq (http://www-huber.embl.de/users/anders/ HTSeq/doc/overview.html). Differentially expressed genes were analysed using DESeq $\mathrm{R}$ software pack. Benjamini-Hochberg multiple testing corrections were employed to reveal the differentially expressed genes.

\section{Validation of mRNA expression by real time RT-PCR}

Total RNA was isolated using Trizol reagent (Invitrogen Life Technologies, Carlsbad, CA) and $3 \mu \mathrm{g}$ of RNA was converted to cDNA using the RevertAid H Minus First Strand cDNA Synthesis Kit (Fermentas, Waltham, MA) following the manufacturer's instructions. Real time PCR was performed on a Light Cycler 480 (Roche, Basel, Switzerland) detection system using SYBR Green I Master mix (Roche, Basel, Switzerland) in 96-well plates. All reactions were run in triplicates and relative gene expression was normalized to steady state expression of GAPDH, calculations made by using the $2-\Delta \Delta \mathrm{Ct}$ method.

\section{Results}

\section{Histology of control and cryptorchid testes}

The $\mathrm{H} \& \mathrm{E}$ stained testes sections of control and cryptorchid rat suggest that at $24 \mathrm{~h}$ there was negligible visible change in any stage of spermatogenesis and most of the stages were present (Fig. 1b), as in control (Fig. 1a). However, at $72 \mathrm{~h}$ there was a marked increase in the incidence of germ cell apoptosis predominantly at stages $\mathrm{I}-\mathrm{V}$ and the late stages XI-XIV, while stages $\mathrm{V}-\mathrm{X}$ were comparatively less affected (Fig. 1c). On the other hand, at $120 \mathrm{~h}$ stages I-VI were badly distorted while stages $\mathrm{X}$-XIV were not distinguishable at all. However, stages VII and VIII were visible but cell apoptosis was quite significant (Fig. 1d). There was a significant reduction in number of spermatocytes at $72(P<0.05)$ and $120(P<$ 0.01 ) h of cryptochidism (Fig. 1e). In case of spermatids, a significant reduction in their number was evident at 24 $(P<0.05), 72$ and $120(P<0.001)$ h (Fig. 1f).

\section{Tunnel assay of paraffin embedded testis tissues}

Tunnel assay was performed to check whether the loss of cells in cryptorchid testes was due to heat-induced apoptosis (Fig. 2). Results indicated that apoptosis was induced in testicular germ cells at body temperature and the number of apoptotic cells gradually increased with the duration of heat exposure (Fig. 2a, d, g, j). Though very few yet significant number of apoptotic cells were observed at $24 \mathrm{~h}(P<0.05)$ of heat-stress, the number increased significantly thereafter at $72 \mathrm{~h}(P<0.001)$ and $120 \mathrm{~h}(P<0.001)$ (Fig. $2 \mathrm{~m})$, which was in agreement with $\mathrm{H} \& \mathrm{E}$ data.

\section{Isolation, purification and characterization of primary spermatocytes and round spermatids}

The enzymatic digestion of testicular parenchyma resulted in complete dispersion of testicular cells (Fig. 3a). The two cell types i.e. spermatocytes and round spermatids were isolated up to the purity of $\sim 75 \%$ and $\sim 80 \%$, respectively, by using centrifugal elutriation method. The homogeneity of spermatocytes and round spermatids was 

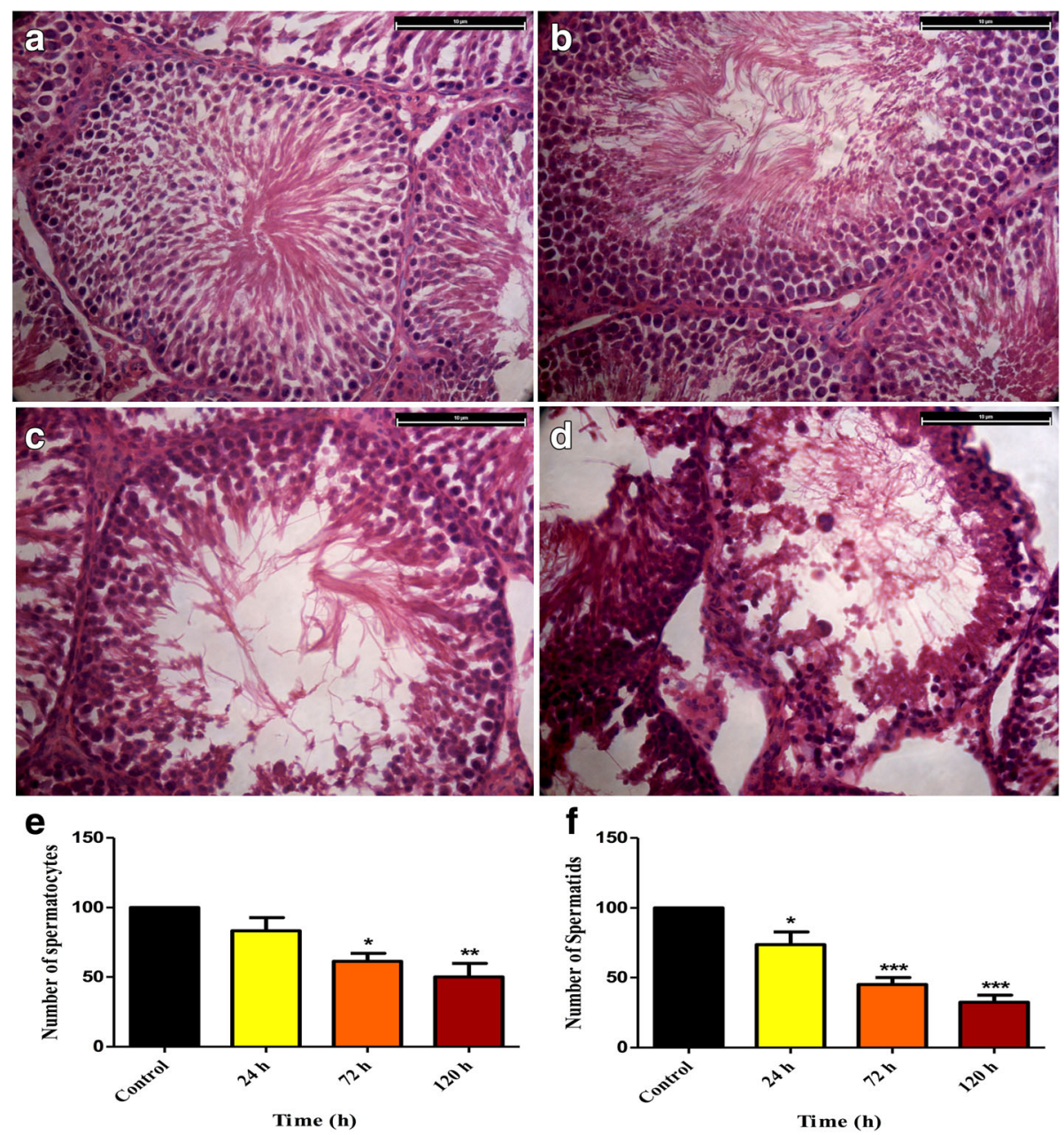

Fig. 1 Representative picture of testes histology at $0 \mathrm{~h}[\mathrm{sham}, \mathbf{a}], 24 \mathrm{~h}[\mathbf{b}], 72 \mathrm{~h}[\mathbf{c}]$ and $120 \mathrm{~h}[\mathbf{d}]$ of cryptorchidism (Bar $=10 \mu \mathrm{m})$. Average number of spermatocytes $(\mathbf{e})$ and spermatids (f) after $0,24,72$ and $120 \mathrm{~h}$ of cryptorchidism. (Mean $\pm \mathrm{SE} ;{ }^{*} P<0.05 ;{ }^{* *} P<0.01 ;{ }^{* * *} P<0.001$ )

further increased to $\sim 90$ and $>92 \%$, respectively, by Percoll density gradient centrifugation method (Fig. $3 \mathrm{~b}$ and c). The purity of the two cell types was confirmed by FACS, which exhibited a single peak in both the cell preparations with negligible number of contaminating cells (Fig. 3d and e). The trypan blue exclusion test showed > $95 \%$ viability of the purified cells in the two fractions (data not shown).

\section{Transcriptome profiling and differential gene expression analysis}

Total RNA was extracted from highly purified primary spermatocytes and round spermatids, isolated from the testicular tissues of all the experimental groups, and subjected to sequencing using Illumina NextSeq 2500. We performed pairwise differential gene expression (DGE) comparisons between samples to detect the genes exhibiting differences in expression by at least 2 -fold. The transcriptome from spermatocytes of control testis (0-Cr-Sc) was compared with that of $24 \mathrm{~h}$ crypt (24-Cr-Sc) and $72 \mathrm{~h}$ crypt (72-Cr-Sc) testes. Similarly, the transcriptome from control spermatids (0-Cr-Sd) was compared with 24, 72 and $120 \mathrm{~h}$ crypt spermatids (24-Cr-Sd; 72-Cr-Sd; 120-Cr-Sd). In spermatocytes, the expression of total 1602 genes was altered (897 up regulated and 705 down regulated) after $24 \mathrm{~h}$ of cryptorchidism, and the expression of 1807 genes was altered (987 up regulated and 820 down regulated) after $72 \mathrm{~h}$ of cryptorchidism. Similarly in spermatids, after 24, 72, $120 \mathrm{~h}$ of cryptorchidism altered expression of 1210 (505 up regulated and 705 down regulated), 1718 (990 up regulated and 728 down regulated) and 3559 (2180 up regulated and 1379 down regulated) transcripts, respectively, was seen. The genes showing change in the expression within $24 \mathrm{~h}$ could be categorized as early response genes while those showing alteration after $24 \mathrm{~h}$ could be termed as mid and late 


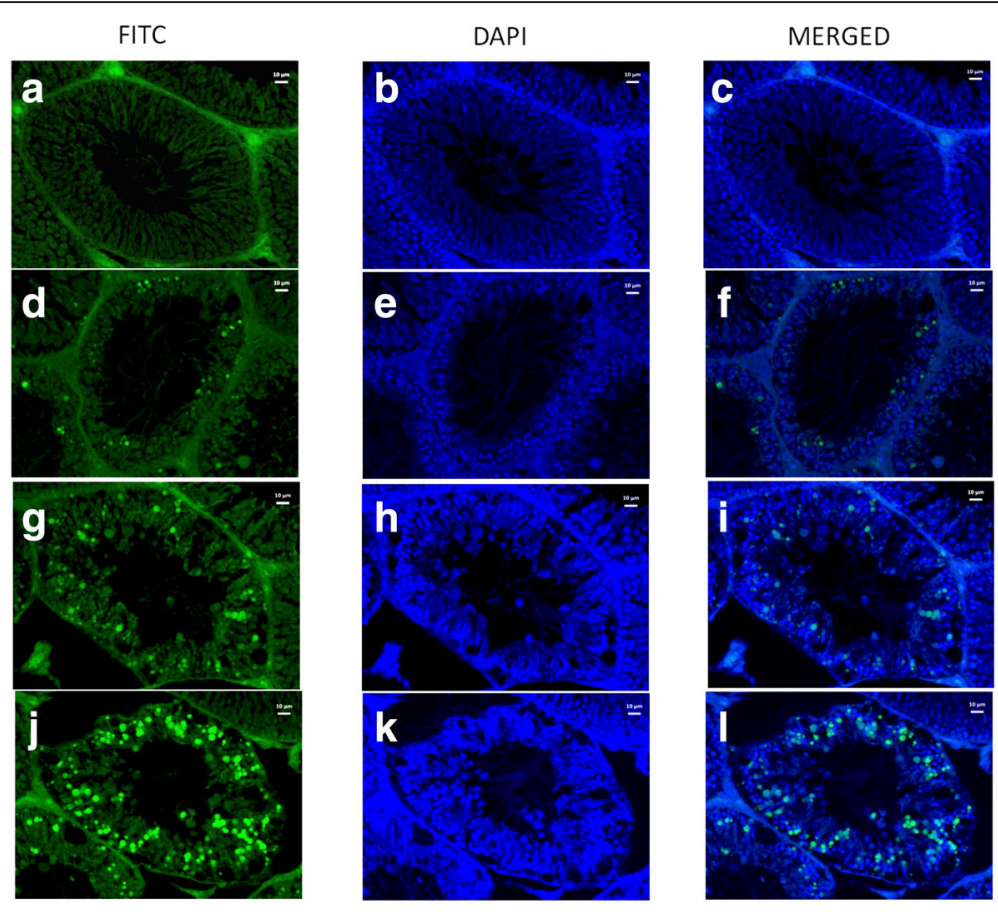

$\mathbf{m}$

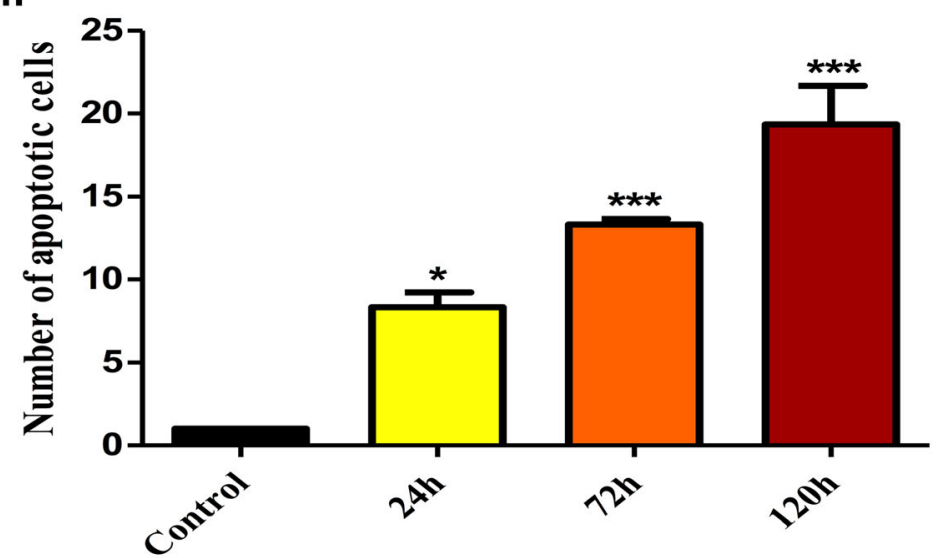

Time (h)

Fig. 2 Apoptosis of germ cells by Tunel Assay in rat testis at $0 \mathrm{~h}[1 \mathbf{a}, \mathbf{b}, \mathbf{c}] ; 24 \mathrm{~h}[1 \mathbf{d}, \mathbf{e}, \mathbf{f}] ; 72 \mathrm{~h}[1 \mathbf{g}, \mathbf{h}, \mathbf{i}]$ and $120 \mathrm{~h}[1 \mathbf{j}, \mathbf{k}, \mathbf{l}]$ of cryptorchidism. (a $\mathbf{d}, \mathbf{g}, \mathbf{j}$ - FITC staining for DNA fragmentation; $\mathbf{b}, \mathbf{e}, \mathbf{h}, \mathbf{k}$ - DAPI staining of DNA; $\mathbf{c}, \mathbf{f}, \mathbf{i}, \mathbf{I}$ - merged images) (Bar $=10 \mu \mathrm{m})$. Average number of TUNEL positive cells (M; Mean $\left.\pm \mathrm{SE} ;{ }^{*} P<0.05 ;{ }^{* * *} P<0.001\right)$

response genes. Overall observations clearly indicate that the number of genes with altered expression increased with an increase in the time period of heat exposure.

Venn analysis indicated that all through $24-72 \mathrm{~h}$ of cryptorchidism, a total of 286 genes were up-regulated and 308 genes were down-regulated in spermatocytes. Similarly, in spermatids 105 genes were up-regulated and 49 genes were down-regulated during 24-120 h of cryptorchidism. Further, Venn analysis suggested that 62 genes were altered in both the cell types during the entire period of hyperthermia (Fig. 4). A heat map of the expression profile of temperature-sensitive genes in the two cell types has been prepared (Fig. 5). A number of genes showed more than one transcript variant, which exhibited different expression patterns in spermatocytes and spermatids.

\section{Gene ontology}

With the aim of finding the pathways/biological processes prominently affected by heat stress, gene ontology of 62 crucial genes was performed. The PANTHER online analysis tool indicated that the 

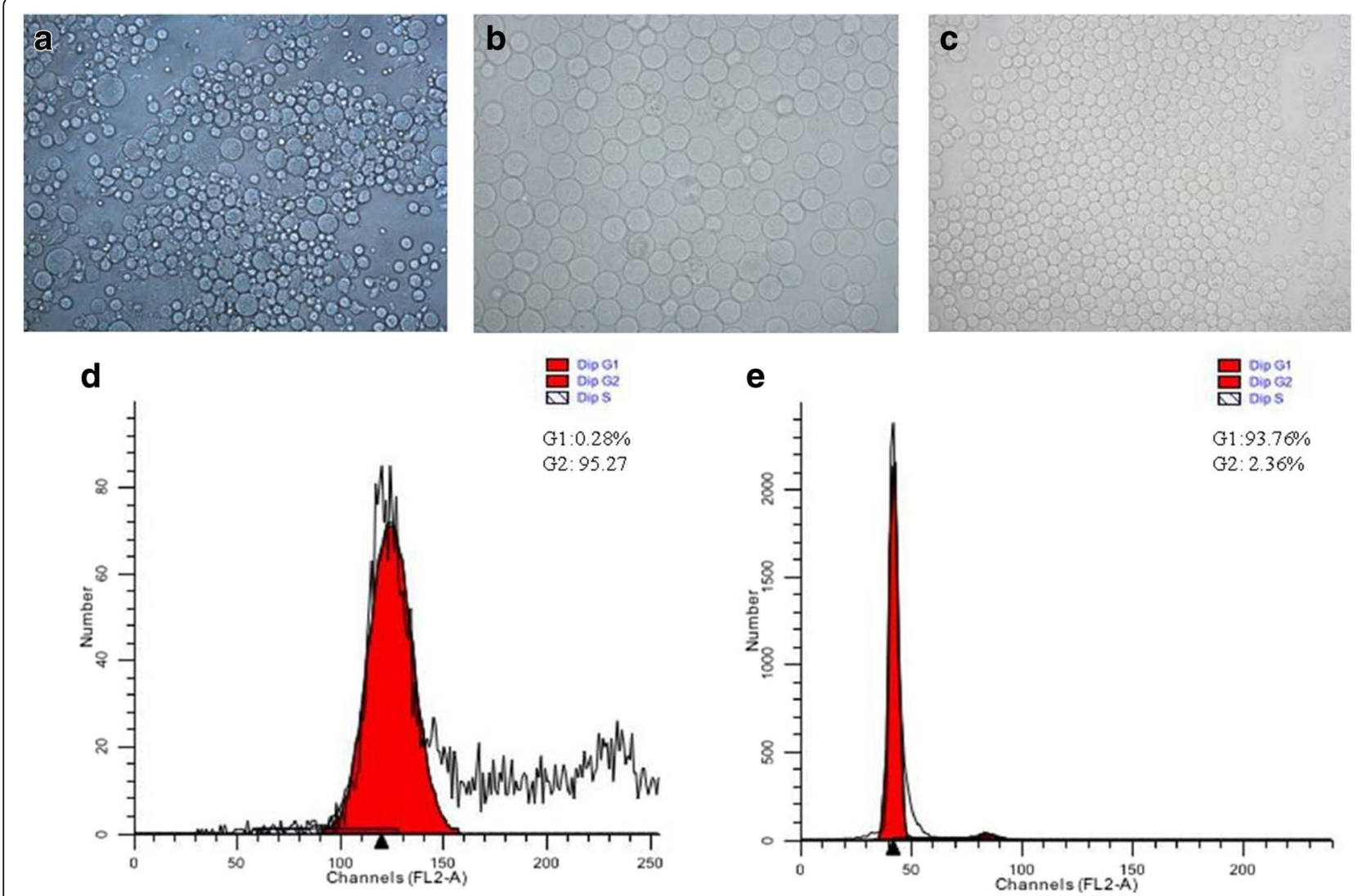

Fig. 3 Isolation and purification of pachytene spermatocytes and round spermatids from rat testes. a-Mixed population after trypsin digestion; bpurified pachytene spermatocytes $(\sim 90 \%)$, c-purified round spermatids (>90\%), $\mathbf{d}$-cell cycle analysis of spermatocyte fraction and $\mathbf{e}$ - cell cycle analysis of spermatid fraction by Flow Cytometry

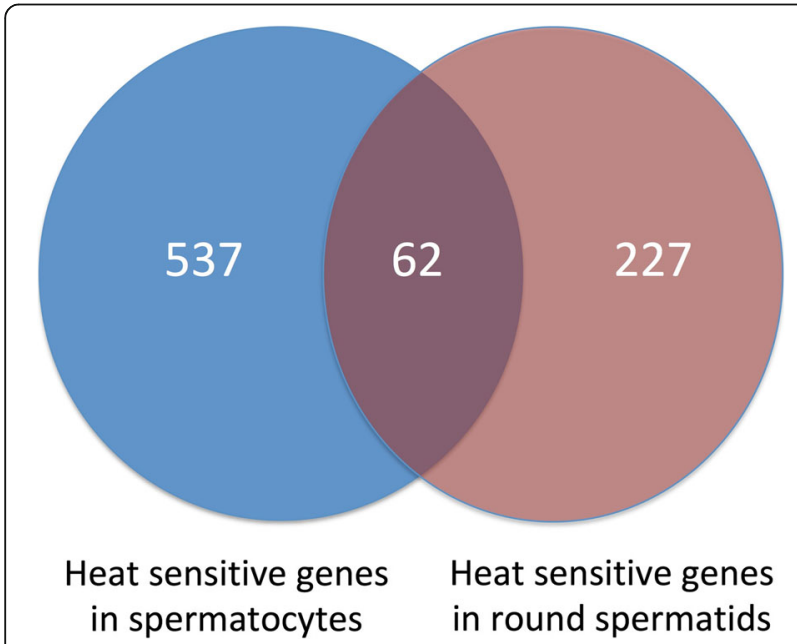

Fig. 4 Venn diagram showing heat-sensitive genes in spermatocytes and spermatids affected transcripts had catalytic (26), binding (21), structural (7), and transporter (6) functions (Table 1). These transcripts were mostly related to cellular (29) and metabolic processes (26), or to biological regulation (6), localization (9), reproduction (1), developmental process (6), or to cellular component organization and biogenesis (8). A single gene may be involved in more than one process. According to the PANTHER tool, the shortlisted genes encoded proteins belonging to the class of nucleic acid binding (9), enzyme modulators (5), hydrolases (8), transferases (5), transcription factors (4), and signaling molecules (3).

\section{Validation of deep sequencing data by qPCR}

For validation of deep sequencing data, we selected 15 heat-sensitive genes related to important biological processes i.e. metabolism (Mct1, Mct2, Mct4, Glut3, Ldhc), lipid biogenesis (Acly), ROS and $\mathrm{Ca}^{++}$mediated signaling pathway (Daxx, Camk2d), apoptotic signaling pathway (p53, Daxx), gene expression 


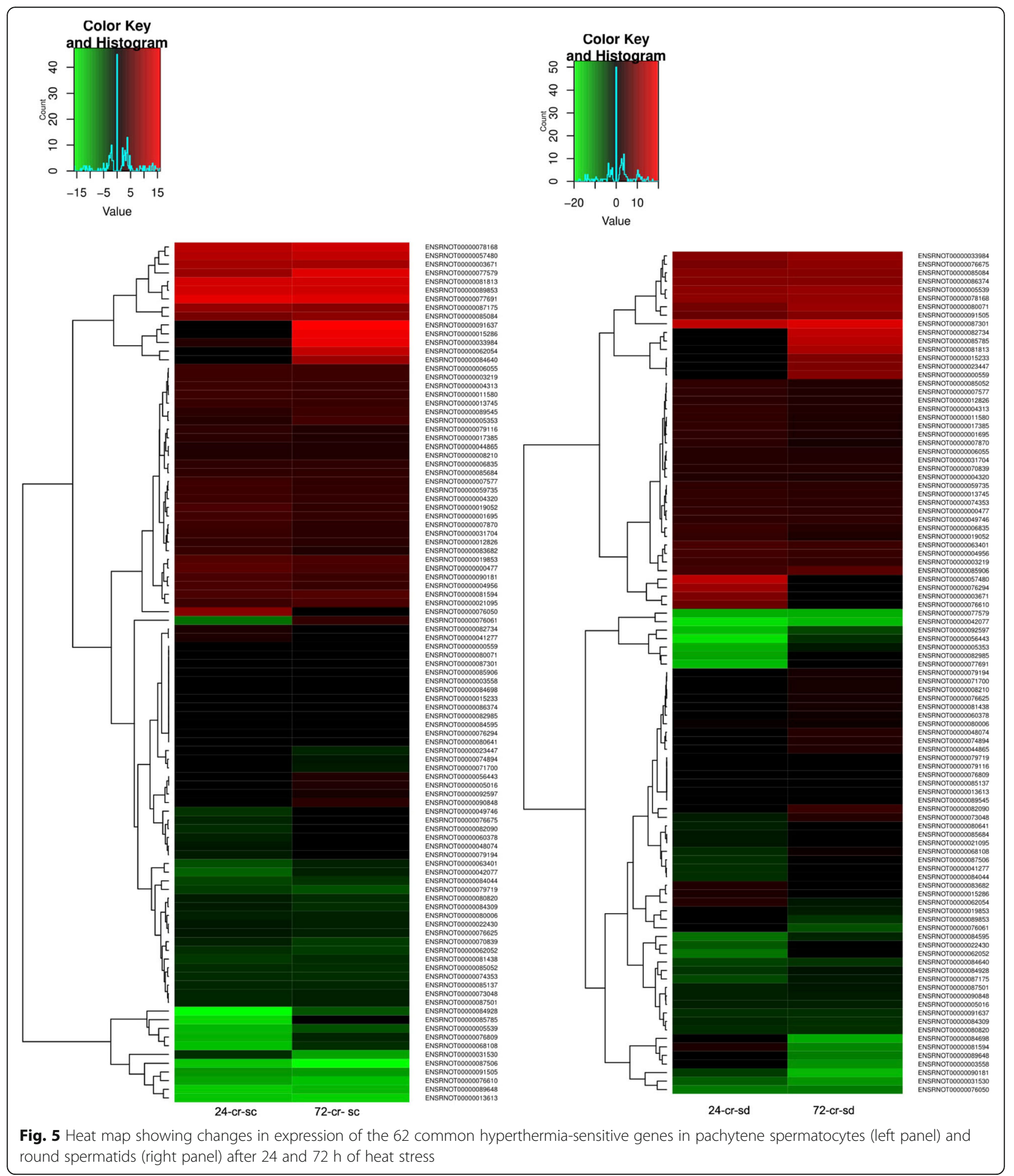

regulation (Taf9, Gtf2b, Cnot8), spermatogenesis (spata22), redox pathway (Txnrd1) and mitochondria related pathway (Mrps14) for validation by RT-PCR. For all the 15 genes, the $\mathrm{qPCR}$ data followed almost the same pattern as depicted by sequencing data for both the cell types (Fig. 6).
miRNA profiling of heat stressed spermatocytes and spermatids by deep sequencing

Similar to mRNA sequencing data analysis, we also performed miRNA sequencing data analysis for spermatocytes and round spermatids from normal and cryptorchid rat testes. A change of $\geq 1.5$ fold in 
Table 1 Gene ontology of genes affected by heat in both spermatocytes and spermatids

\begin{tabular}{|c|c|c|}
\hline & $\begin{array}{l}\text { Nō. of } \\
\text { genes }\end{array}$ & Name of genes \\
\hline \multicolumn{3}{|l|}{ Molecular functions } \\
\hline Binding (GO:0005488) & 21 & $\begin{array}{l}\text { Taf9, Cast, Apbb1, Crip1, Zfp202, Timp1, Lilrb31, AC120291 (Mbd3), Sptbn1, Cast, Sept4, } \\
\text { AC120291 (Mex3d), Prpf8, Rabgap11, Gtf2b, Tdrd5, Micu1, Upf1, Prelp, Micu2, Camk2d }\end{array}$ \\
\hline Catalytic activity (GO:0003824) & 26 & $\begin{array}{l}\text { Cst, Clk3, Hsd1161, Mink1, Timp1, Abcc12, AC120291 (Atp8b3), Scpep1, Cast, Sept4, } \\
\text { Grip1, AC120291 (Mex3d), Acly, Serpinf1, Prpf8, Ptpru, Rabgap11, Tdrd5, Txnrd1, Upf1, } \\
\text { Nt5c3b, Idhc, Mipep, Scamp1, LOC316124, Camk2d }\end{array}$ \\
\hline Receptor activity (GO:0004872) & 2 & Lilrb3l, Ptpru \\
\hline Signal transducer activity (GO:0004871) & 1 & Mink1 \\
\hline Structural molecule activity (GO:0005198) & 7 & Emp1, Crip1, Mgp, C1qa, Sptbn1, Sept4, Mrps 14 \\
\hline Transporter activity (GO:0005215) & 6 & Abcc12, AC120291 (Atp8b3), Mct4, LOC316124, Mct2,Mct1 \\
\hline \multicolumn{3}{|l|}{ Biological process } \\
\hline Biological adhesion (GO:0022610) & 7 & Cfb, Col6a2, Ccdc80, C1qa, Cfb, Rabgap11, Prelp \\
\hline Biological regulation (GO:0065007) & 6 & Crip1, Mink1, Timp1, AC120291 (Atp8b3), AC120291 (Mbd3), Serpinf1 \\
\hline $\begin{array}{l}\text { Cellular component organization or } \\
\text { biogenesis (GO:0071840) }\end{array}$ & 8 & Col6a2, Crip1, Mink1, AC120291 (Atp8b3), C1qa, AC120291 (Mbd3) \\
\hline Cellular process (GO:0009987) & 29 & $\begin{array}{l}\text { Emp1, Cfb, Col6a2, Apbb1, Ccdc80, AC120291 (PIk5), Zfp202, Mink1, Timp1, AC120291 } \\
\text { (Atp8b3), C19a, Lilrb31, AC120291 (Mbd3), Wdr36, Scpep1, Sptbn1, Cfb, Sept4, Grip1, } \\
\text { Prpf8, Rabgap11, Prkar2b, Upf1, Prelp, Mipep, Mct4, Mrps14, Mct2, Camk2d }\end{array}$ \\
\hline Developmental process (GO:0032502) & 6 & Crip1, Mink1, C1qa, Sptbn1, Prelp, Camk2d \\
\hline Immune system process (GO:0002376) & 9 & Cfb, Col6a2, Crip1, Ccdc80, Abcc12, C1qa, Col3a1, Cfb, LOC316124 \\
\hline Localization (GO:0051179) & 9 & Abcc12, AC120291, Cast, Rabgap11, Scamp1, Mct4, LOC316124, Mct2, Mct1 \\
\hline Metabolic process (GO:0008152) & 26 & $\begin{array}{l}\text { Taf9, Cast, Apbb1, Crip1, Zfp202, Hsd1161, Mink1, Timp1, AC120291 (Atp8b3), } \\
\text { AC120291 (Mbd3), Wdr36, Scpep1, AC120291 (Mex3d), Acly, Prpf8, Ptpru, Sdhaf3, } \\
\text { Gtf2b, Tdrd5, Txnrd1, Upf1, Idhc, Prelp, Mipep, LOC316124, Mrps14 }\end{array}$ \\
\hline Multicellular organismal process (GO:0032501) & 4 & Mink1, Col3a1, Grip1, Prelp \\
\hline Reproduction (GO:0000003) & 1 & Crip1 \\
\hline Response to stimulus (GO:0050896) & 8 & Taf9, Cfb, Lilrb3, Crip1, Mink1, Timp1, Abcc12, Cfb \\
\hline \multicolumn{3}{|l|}{ Cellular Component } \\
\hline Cell junction (GO:0030054) & 1 & Grip1 \\
\hline Cell part (GO:0044464) & 15 & $\begin{array}{l}\text { Emp1, Apbb1, Crip1, Zfp202, Mink1, AC120291 (Atp8b3), AC120291 } \\
\text { (Mbd3), Wdr36, Sptbn1, Sept4, Prpf8, Ptpru, Mipep, Mrps14, Camk2d }\end{array}$ \\
\hline Extracellular matrix (GO:0031012) & 4 & Col6a2, Timp1, C1qa, Prelp \\
\hline Extracellular region (GO:0005576) & 4 & Timp1, C1qa, Serpinf1, Prelp \\
\hline Macromolecular complex (GO:0032991) & 3 & Wdr36, Prpf8, Mrps 14 \\
\hline Membrane (GO:0016020) & 4 & AC120291 (Atp8b3), Grip1, Mct4, Mct1 \\
\hline Organelle (GO:0043226) & 9 & $\begin{array}{l}\text { Apbb1, Zfp202, AC120291 (Atp8b3), AC120291 (Mbd3), AC120291, Sept4, Prpf8, } \\
\text { Prelp, Mipep }\end{array}$ \\
\hline \multicolumn{3}{|l|}{ Protein class } \\
\hline Calcium-binding protein (PC00060) & 3 & Mgp, Micu1, Micu2 \\
\hline Cell adhesion molecule (PC00069) & 1 & Clqa \\
\hline Cell junction protein (PC00070) & 1 & Grip1 \\
\hline Cytoskeletal protein (PC00085) & 5 & Emp1, Crip1, Ivns1abp, Sptbn1, Sept4 \\
\hline Defense/immunity protein (PC00090) & 1 & Lilrb3l \\
\hline Enzyme modulator (PC00095) & 5 & Cast, Cast (Erc2), Sept4, Serpinf1, Rabgap 11 \\
\hline Extracellular matrix protein (PC00102) & 3 & Mgp, Clqa, Prelp \\
\hline Hydrolase (PC00121) & 8 & Ivns1abp, AC120291 (Atp8b3), Scpep1, Ptpru, Rabgap1I, Upf1, Nt5c3b, Mipep \\
\hline Ligase (PC00142) & 3 & AC120291 (Mex3d), Acly, LOC316124 \\
\hline
\end{tabular}


Table 1 Gene ontology of genes affected by heat in both spermatocytes and spermatids (Continued)

\begin{tabular}{|c|c|c|}
\hline & $\begin{array}{l}\text { Nō. of } \\
\text { genes }\end{array}$ & Name of genes \\
\hline lyase (PC00144) & 1 & Acly \\
\hline Membrane traffic protein (PC00150) & 1 & Cast \\
\hline Nucleic acid binding (PC00171) & 9 & Taf9, Crip1, AC120291 (Mbd3), Wdr36, AC120291 (Mex3d), Prpf8, Tdrd5, Upf1, Mrps14 \\
\hline Oxidoreductase (PC00176) & 3 & Hsd11b1, Txnrd1, Idhe \\
\hline Signaling molecule (PC00207) & 3 & Apbb1, Mgp, Lilrb3l \\
\hline Structural protein (PC00211) & 1 & Mgp \\
\hline Transcription factor (PC00218) & 4 & Taf9, Crip1, Ivns1abp, Gtf2b \\
\hline Transferase (PC00220) & 5 & Clk3, Grip1, Acly, Scamp1, Camk2d \\
\hline Transporter (PC00227) & 5 & Abcc12, AC120291 (Atp8b3), Mct4, Mct2, Mct1 \\
\hline Transfer carrier protein & 1 & Scamp1 \\
\hline Receptors & 2 & Ptpru, Prelp \\
\hline \multicolumn{3}{|l|}{ Pathways } \\
\hline Alzheimer disease-amyloid secretase pathway (P00003) & 1 & Apbb1 \\
\hline Alzheimer disease-presenilin pathway (P00004) & 1 & Apbb1 \\
\hline Angiogenesis (P00005) & 1 & AC120291 (Apc2) \\
\hline Cytoskeletal regulation by Rho GTPase (P00016) & 2 & $\operatorname{Arpc2}, \mathrm{Gtf2b}$ \\
\hline General transcription regulation (P00023) & 2 & Taf9, Gtf2b \\
\hline $\begin{array}{l}\text { Inflammation mediated by chemokine and cytokine } \\
\text { signaling pathway (P00031) }\end{array}$ & 3 & Col6a2, Arpc2, camk2d \\
\hline Integrin signalling pathway (P00034) & 3 & Col6a2, Arpc2, Col3a1 \\
\hline Parkinson disease (P00049) & 1 & Sept4 \\
\hline Pyruvate metabolism (P02772) & 1 & Acly \\
\hline $\begin{array}{l}\text { Transcription regulation by bZIP transcription } \\
\text { factor (P00055) }\end{array}$ & 3 & Taf9, Gtf2b, Prkar2b \\
\hline Wnt signaling pathway (P00057) & 1 & AC120291 (Apc2) \\
\hline 5HT receptor Mediated signaling & 1 & Prkar2b \\
\hline Apoptosis signalling pathway & 1 & daxx \\
\hline b 1 adrenergic signaaling & 1 & Prkar2b \\
\hline b2 adrenegenic signalling & 1 & Prkar2b \\
\hline dopamine receptor mediated signaling & 1 & Prkar2b \\
\hline fas signalling pathway & 1 & $\operatorname{daxx}$ \\
\hline endothilin signalling pathway & 1 & Prkar2b \\
\hline muscarinie acetylcholine receptor 2 and 4 signalling & 1 & Prkar2b \\
\hline metabotropic glutamate receptor III pathway & 1 & Prkar2b \\
\hline metabotropic glutamate receptor II pathway & 1 & Prkar2b \\
\hline ionotropic glutamate receptor pathway & 1 & Camk2d \\
\hline GABA b receptor signaling & 1 & Prkar2b \\
\hline
\end{tabular}

expression of miRNAs under heat stress was considered as significant. In spermatocytes, after 24,72 and $120 \mathrm{~h}$ of cryptorchidism, 175 (93 upregulated and 82 down regulated), 185 (71 upregulated and 114 down regulated) and 280 (126 upregulated and 154 down regulated) miRNAs exhibited altered expression, respectively. Venn analysis (Fig. 7) indicated that 66 miRNAs remained affected throughout 24-120 $\mathrm{h}$ of heat stress in spermatocytes, which included 3 novel miRNAs (Table 2). On the other hand, in spermatids after 24, 72 and 120 h of cryptorchidism, 265 (147 upregulated and 118 down 


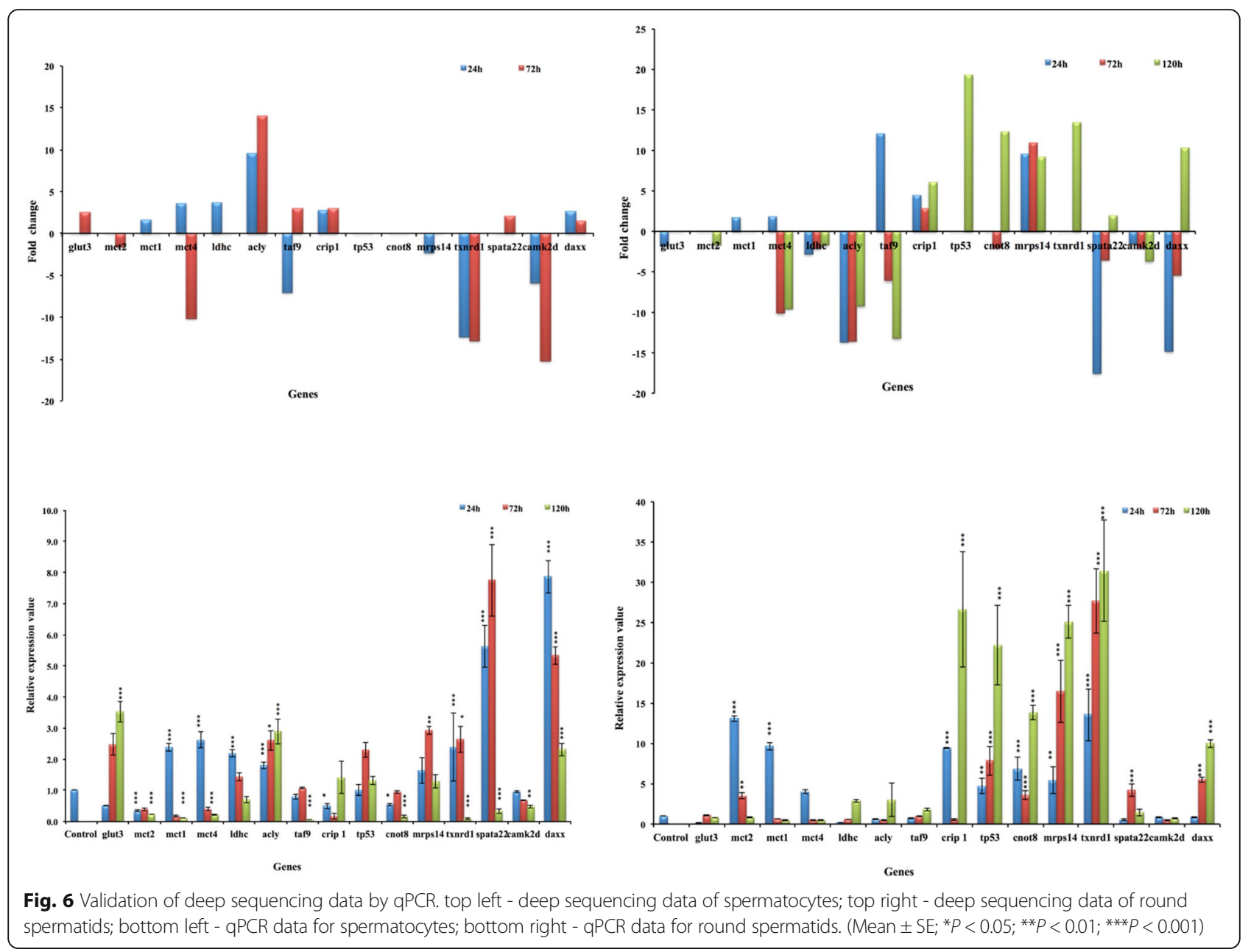

regulated), 301 (160 upregulated and 141 down regulated), and 328 (162 upregulated and 166 down regulated) genes exhibited altered expression, respectively. Venn analysis (Fig. 7) showed that 60 miRNAs (including 6 novel) (Table 2) remained significantly affected throughout 24-120 h of cryptorchidism. The heat map of the expression profile of common miRNAs in both the cell types is presented in Fig. 8.

\section{Prediction of novel miRNAs}

Among novel miRNAs, we identified 3 and 6 miRNAs that were most heat-sensitive in spermatocytes and round spermatids, respectively (Table 3 ).

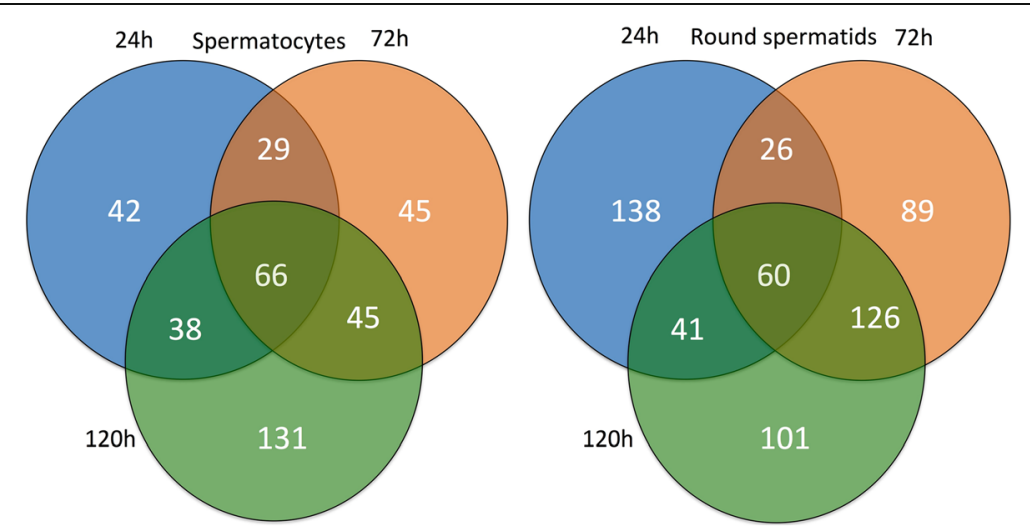

Fig. 7 Venn diagram showing heat-sensitive miRNAs in spermatocytes and round spermatids 
Table 2 miRNAs with altered expression in spermatocytes and round spermatid under heat stress

\begin{tabular}{|c|c|}
\hline Major miRNAs altered by heat in spermatocytes & Major miRNAs altered by heat in round spermatids \\
\hline $\begin{array}{l}\text { bta-miR-339a; bta-miR-339b; bta-miR-423-3p; bta-miR-99a-5p; cfa-miR-101; } \\
\text { cfa-miR-1306; cgr-miR-28-5p; cgr-miR-298-5p; chi-miR-15a-5p; efu-miR-29a; } \\
\text { efu-miR-34a; efu-miR-381; ggo-miR-146a; ggo-miR-148a; ggo-miR-151a; } \\
\text { ggo-miR-381; hsa-let-7c-5p; } \\
\text { hsa-miR-100-5p; hsa-miR-101-3p; hsa-miR-10a-5p; hsa-miR-1306-5p; } \\
\text { hsa-miR-148a-3p; } \\
\text { hsa-miR-202-5p; hsa-miR-28-5p; hsa-miR-381-3p; hsa-miR-423-3p; } \\
\text { hsa-miR-99a-5p; } \\
\text { mdo-miR-100-5p; mdo-miR-10b-5p; mdo-miR-199b-2-5p; mmu-let-7i-5p; } \\
\text { mmu-miR-101c; mmu-miR-146a-5p; mmu-miR-151-5p; } \\
\text { mmu-miR-201-5p; mmu-miR-202-5p; mmu-miR-296-5p; mmu-miR-298-5p; } \\
\text { mmu-miR-300-3p; mmu-miR-3074-5p; mmu-miR-3470b; mmu-miR-501-3p; } \\
\text { mmu-miR-674-3p; Novel_1015; Novel_3011; Novel_66; oan-miR-1386; } \\
\text { oar-miR-10a; oar-miR-374b; } \\
\text { oar-miR-99a; ppy-miR-378d; rno-miR-148a-5p; rno-miR-25-5p; } \\
\text { rno-miR-339-5p; rno-miR-3560; rno-miR-3585-5p; rno-miR-3586-3p; } \\
\text { rno-miR-466c-5p; rno-miR-483-3p; rno-miR-501-3p; rno-miR-547-3p; } \\
\text { rno-miR-676; } \\
\text { sha-miR-202; ssc-let-7i; ssc-miR-186; ssc-miR-339 }\end{array}$ & $\begin{array}{l}\text { bta-miR-22-3p; bta-miR-3600; bta-miR-363; cgr-miR-222-3p; cgr-miR-24-5p; } \\
\text { cgr-miR-28-5p; cgr-miR-664-3p; cgr-miR-7b; chi-miR-361-3p; chi-miR-363- } \\
\text { 3p; efu-miR-30a; } \\
\text { efu-miR-34a; efu-miR-7a; efu-miR-7b; ggo-miR-151a; ggo-miR-328; } \\
\text { ggo-miR-423; hsa-miR-100-5p; hsa-miR-151b; hsa-miR-22-3p; } \\
\text { hsa-miR-22-5p; hsa-miR-3184-3p; hsa-miR-32-3p; hsa-miR-361-3p; } \\
\text { hsa-miR-423-5p; hsa-miR-449b-5p; mdo-miR-100-5p; mdo-miR-106-5p; } \\
\text { mdo-miR-15a-5p; mdo-miR-22-3p; mml-miR-32-3p; mml-miR-411-3p; } \\
\text { mml-miR-99b-3p; mmu-miR-129-5p } \\
\text { mmu-miR-151-5p; mmu-miR-204-3p; mmu-miR-24-2-5p; mmu-miR-28c; } \\
\text { mmu-miR-301a-5p; mmu-miR-3074-2-3p; mmu-miR-32-3p; mmu-miR- } \\
\text { 7b-5p; mmu-miR-99b-3p; } \\
\text { mmu-miR-99b-5p; Novel_1113; Novel_1204; Novel_2956; Novel_3356; } \\
\text { Novel_4066; Novel_4398; rno-miR-298-3p; } \\
\text { mo-miR-301a-5p; rno-miR-32-3p; rno-miR-328a-3p; rno-miR-3586-3p; } \\
\text { rno-miR-411-3p; } \\
\text { rno-miR-423-5p; rno-miR-664-3p; ssc-miR-20a; ssc-miR-411 }\end{array}$ \\
\hline
\end{tabular}

\section{Target prediction of heat-sensitive miRNAs in round} spermatids and gene ontology of predicted targets The heat-sensitive miRNAs, among known miRNAs in rat species, were selected for target prediction. The gene ontologies of predicted targets have been detailed for spermatocytes (Table 4) and spermatids (Table 5).

The crucial thermo-sensitive genes regulated tightly by miRNAs have been selected with the help of online miRDB tool. The table below lists the most heat sensitive miRNAs and their probable target proteins in temperature vulnerable meiotic and post-meiotic germ cells of rat testis at 24/72/120 h of heat stress, during which their numbers decrease to significantly low numbers. Capturing molecular changes early in heat exposure could identify the core thermo-regulators, while longer exposure may result in a host of secondary molecular changes, which may not be the key thermo-regulators.

\begin{tabular}{|c|c|c|c|c|}
\hline $\begin{array}{l}\text { Thermo- } \\
\text { sensitive } \\
\text { miRNAs }\end{array}$ & $\begin{array}{l}\text { Fold change } \\
\text { in miRNA }\end{array}$ & $\begin{array}{l}\text { Fold change } \\
\text { in target } \\
\text { mRNA }\end{array}$ & $\begin{array}{l}\text { Predicted } \\
\text { gene } \\
\text { targets }\end{array}$ & Cell Type \\
\hline rno-miR-22-3P & +3.4 & -13.5 & Acly & Spermatid \\
\hline rno-miR-22-5P & +1.8 & -13.5 & Acly & Spermatid \\
\hline rno-miR-129-5P & -1.9 & +8.5 & selV & Spermatocyte \\
\hline rno-miR-3560 & +2.1 & -1.6 & MCT2 & Spermatocyte \\
\hline rno-miR-3560 & +2.1 & -12.3 & Txnrd1 & Spermatocyte \\
\hline rno-miR-466c-5P & +1.5 & -1.8 & Prkar2B & Spermatid \\
\hline
\end{tabular}

\section{Discussion}

Crytorchidism is a state wherein the loss of germ cells takes place by apoptosis leading to infertility, and transient testicular heating has been shown to provide reversible contraception in men [25] and temporary sterility in rats [26]. Therefore, determining the dynamics of gene expression during spermatogenesis under heat stress could be advantageous in identifying key heat-sensitive genes regulating gamete production for the development of male contraceptives. While a few studies have investigated the differential gene expression (DGE) in mouse during normal spermatogenesis [20-22], none has tried to study the regulation of transcriptome in the vulnerable germ cell types (spermatocytes and spermatids) during cryptorchidism. A careful analysis of transcriptome data suggested that though there is a general disturbance in metabolic/biological processes and pathways under heat stress in both spermatocytes and spermatids, the most strongly affected genes were related to solute carrier family (transporters), energy metabolism, ROS, ribosomal, ring/zinc finger, proteasomal, ubiquitination, HSPs, transcription factors, apoptotsis and transmembrane proteins. However, the expression profile in the two cell populations was distinct for several genes.

The site of spermatogenesis i.e. seminiferous tubules is one of the most heterogenic niches of the body where about 30 types of cells coexist. These cells not only vary in their size, morphology, and function, but also in their DNA content; e.g. 2C (spermatogonia, Sertoli cells, Leydig cells etc), 4C (G2 phase spermaocytes), and $1 \mathrm{C}$ or $\mathrm{C}$ (round and elongating spermatids, and spermatozoa). The heterogeneity of testicular cells and the lack of in vitro systems for spermatogenic cell culture [27] are the major hurdles in gene expression studies at different stages of spermatogenesis [23]. To overcome this, enrichment of stage-specific germ-cell populations is mandatory. The gravimetric decantation in BSA gradients (staput) [28-30] and the centrifugal elutriation [31] are amongst the most widely used techniques of germ cell enrichment. Using the centrifugal elutriation technique coupled with Percoll ${ }^{\circ}$ density gradient centrifugation, successful enrichment of pachytene spermatocytes and round spermatids to purity 


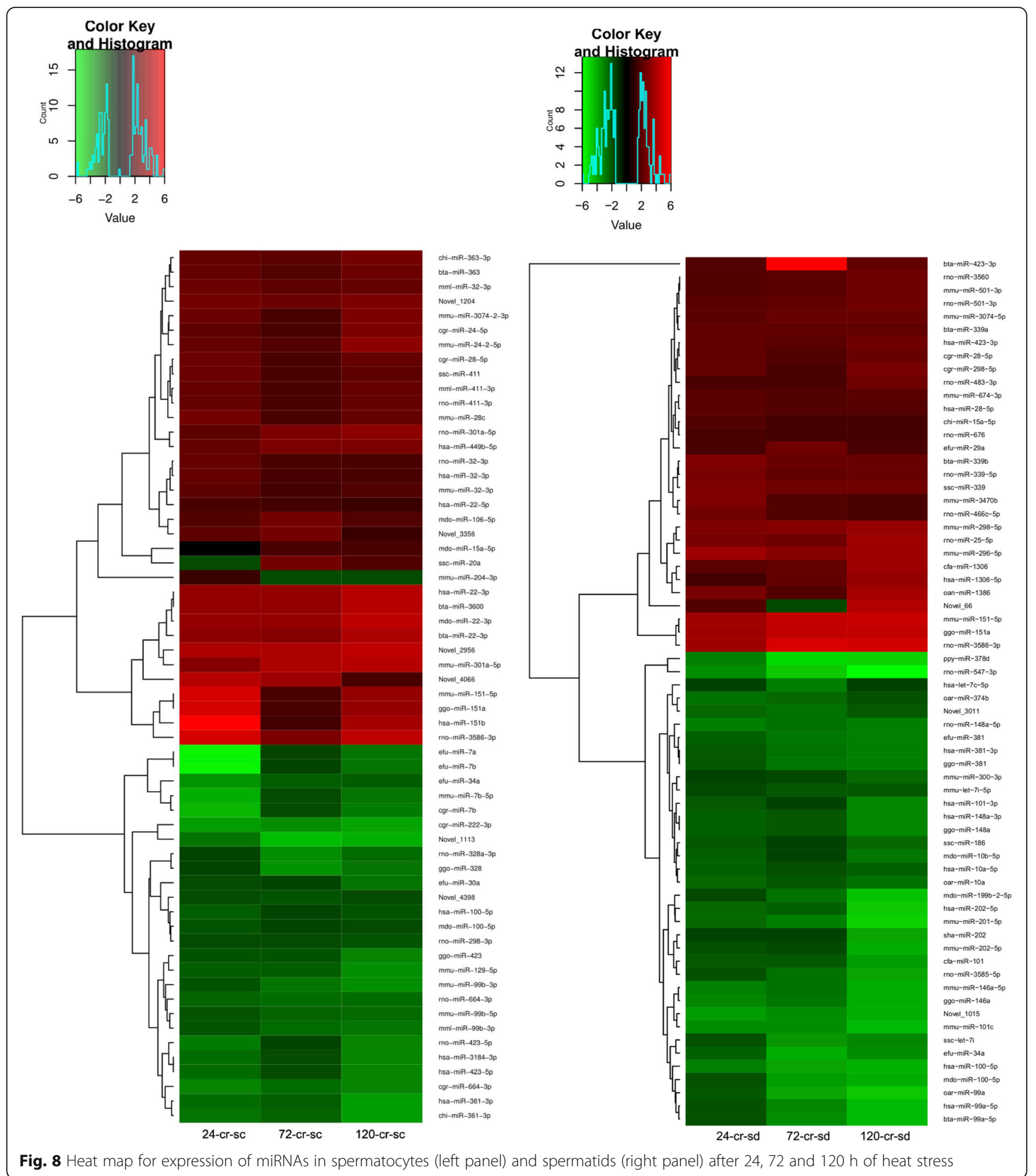

levels of $>90 \%$ was achieved. To our understanding, this is the best method of achieving germ cell purification to a high level. Nevertheless, less than $10 \%$ cross-contamination would not affect the findings of the study except screening out genes with minor differences between the two cell types.
We observed altered expression of HSP members belonging to Hspa, Hsp90, Hspe, Hspd and Hspb. Hspe1 is a mitochondrial co-chaperonin, necessary for the folding of newly imported and stress-denatured mitochondrial proteins and works in association with $H s p 60$ (Hspd) in the presence of ATP [32]. Hspe1 showed > 3.0 fold up-regulation in heat 
Table 3 Details of novel miRNAs common in spermatocytes and round spermatids

\begin{tabular}{clll}
\hline S. no & Name & Sequence & Nucleotide length (bases) \\
\hline Common in spermatids & & & 20 \\
1 & Novel_1204 & CAAGAGGTGCATGCTGACAG & 20 \\
2 & Novel_2956 & GATTAGCTCAGTGGTAGAG & 20 \\
3 & Novel_3356 & GGCTATTCTCGGCTGTCAGC & 20 \\
4 & Novel_4066 & TACCTCACTGTAGTCTAGGG & 24 \\
5 & Novel_4398 & TCCAGGTCCACTCTGCTGAGCACT & 24 \\
Common in round spermatocytes & ATTCTGGCTGTGTCTCTCAGGAGC & 20 \\
7 & Novel_1015 & & 20 \\
9 & Novel_3011 & ATGGGCTGTAGAATTCTCT & 22 \\
\hline
\end{tabular}

stressed round spermatids and its companion protein Hspd1 was up-regulated (3.2 fold) after $120 \mathrm{~h}$ of cryptorchidism. However, in case of pachytene spermatocytes the Hspd1 exhibited higher expression after $24 \mathrm{~h}$ of cryptorchidism but expression of Hspe1 remained unchanged. Thus, it can be assumed that round spermatids could delay the apoptotic response due to heat stress with the help of these HSPs. On the other hand, Hspa13 was continuously down-regulated from $24 \mathrm{~h}$ of heat stressed in both the cell types and maximum down expression ( -9.9 fold) was observed in spermatocytes at $72 \mathrm{~h}$ of heat stress. According to Yunoki et al. [33] Hspa13 is non-inducible to heat stress in human fibroblast cells. Hspa13 is over expressed under UVB treatment and inhibits apoptosis [34] in the presence of alkannin. Thus higher under expression of Hspa13 in spermatocytes suggest higher susceptibility to apoptosis. When we observed expression of $H s f 2$, an important heat stress transcription factor, we didn't find any change in round spermatids while a slight down regulation in spermatocytes was reported.

It is well known that the more mature germ cells, specifically spermatocytes and spermatids, rely on lactate as their energy source [35, 36], which is provided by the Sertoli cells. This lactate is further converted into pyruvate with the help of $L D H c$ and is accompanied by the generation of reduced $\mathrm{NAD}^{+} . L D H c$ is testis specific isozyme of LDH expressed in male germ cells [37]. Moreover the fertility of $L d h c$ null males was severely compromised, which further confirmed the importance of this isozyme in fertility [38]. Due to this fact, $L D H c$ attracted the attention of researchers as a fertility target for developing contraceptive vaccine $[39,40]$. Significant changes in the expression levels of $L D H c$, lactate transporters (MCT1, MCT2, MCT4) and GLUT3 genes in germ cells was observed under heat stress, which were further validated by real time PCR. The lactate formed in the Sertoli cells is transferred to the germ cells with help of monocarboxylate transporters i.e., MCT1, MCT2, MCT4 which are present on germ cells. MCT1 is present on spermatogonia, spermatocytes and spermatids, while MCT2 is reported to be present on the tails of elongated spermatids and sperm [41]. This indicated that the metabolism of heat stressed germ cells is disturbed which may lead to apoptosis of the spermatids and spermatocytes. Furthermore, lactate taken up by germ cells is metabolized to pyruvate with the resultant increase in $\mathrm{NADH}$, which is a substrate for NOX4. Reactive Oxygen Species (ROS) produced by NOX4 activity may act as second messengers in regulating the signal transduction pathways and gene expression. This indicates that besides energy metabolism, lactate also has a paracrine role and may also play a decisive role as a cell-signalling molecule in the seminiferous tubules after being secreted by the Sertoli cells [42].

The other targets include ATP-citrate lyase (ACLY), which is known to be the primary enzyme responsible for the synthesis of cytosolic acetyl-CoA in many tissues for the synthesis of lipids to meet the great demand for membrane expansion of rapidly proliferating cells [43]. Inhibition of ATP citrate lyase $(A C L Y)$, leads to growth suppression and apoptosis in a subset of human cancer cells [44]. In heat stressed testis, the level of Acly was found to be decreased in spermatids which could also be a reason for apoptosis of the germ cells. Acly is target of the miRNAs rno-miR-22-3p and rno-miR-22-5p. Acetyl-CoA is the requisite building block for the endogenous synthesis of fatty acids, cholesterol, and isoprenoids as well as acetylation reactions that modify proteins. ACL-generated oxaloacetate is reduced to malate, which can return to the mitochondria, recycling carbon and shuttling reducing equivalents into the mitochondria. The conversion of cytosolic oxaloacetate to malate is driven by the high cytosolic NADH/NAD+ ratio present in glycolytic cells. Malate can enter the mitochondrial matrix and be converted there to oxaloacetate to complete the substrate cycle. The coupled conversion of NAD+ to NADH provides a continuing mechanism to preserve the mitochondrial membrane potential (MMP) and sustain a high 


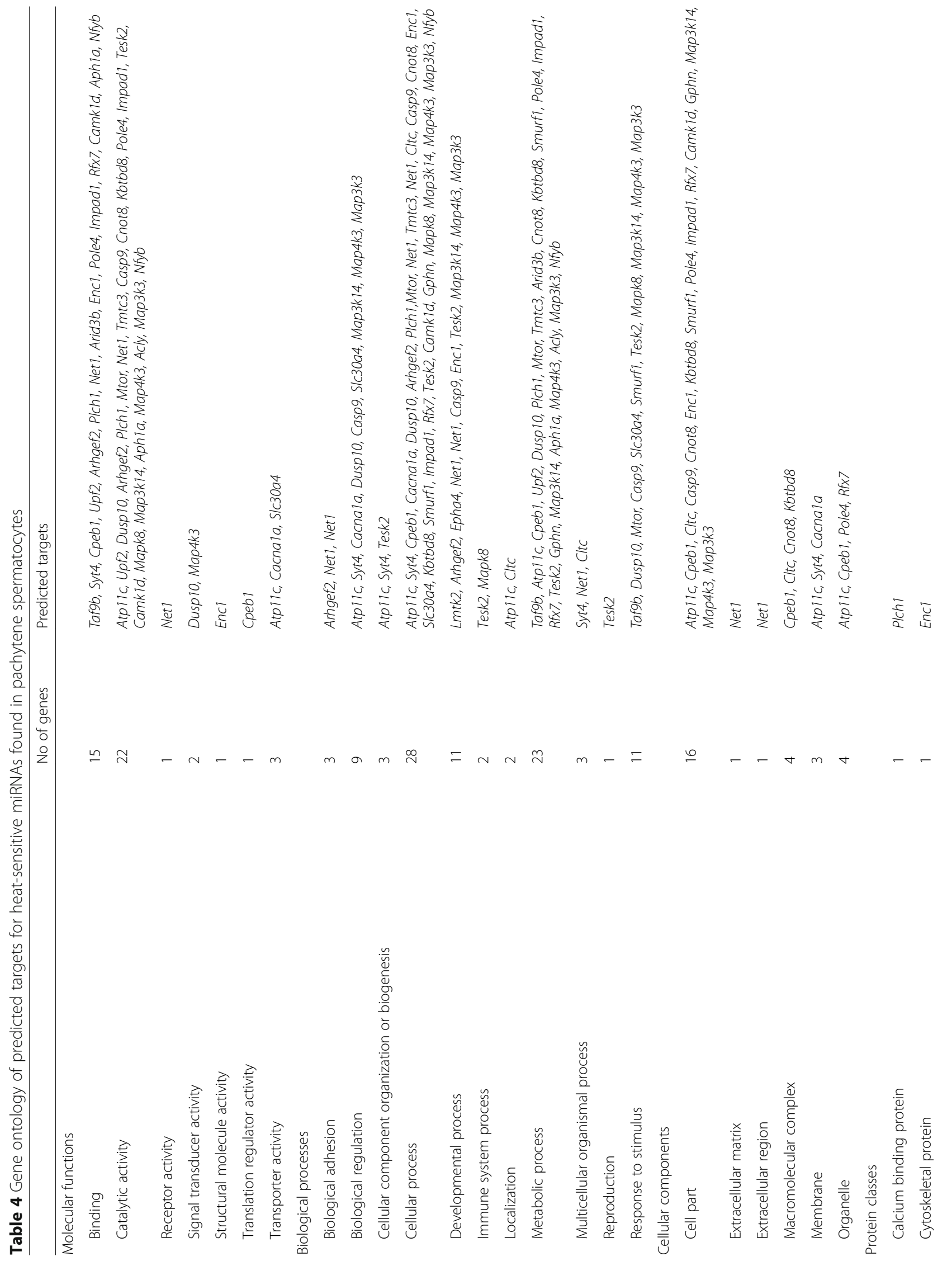




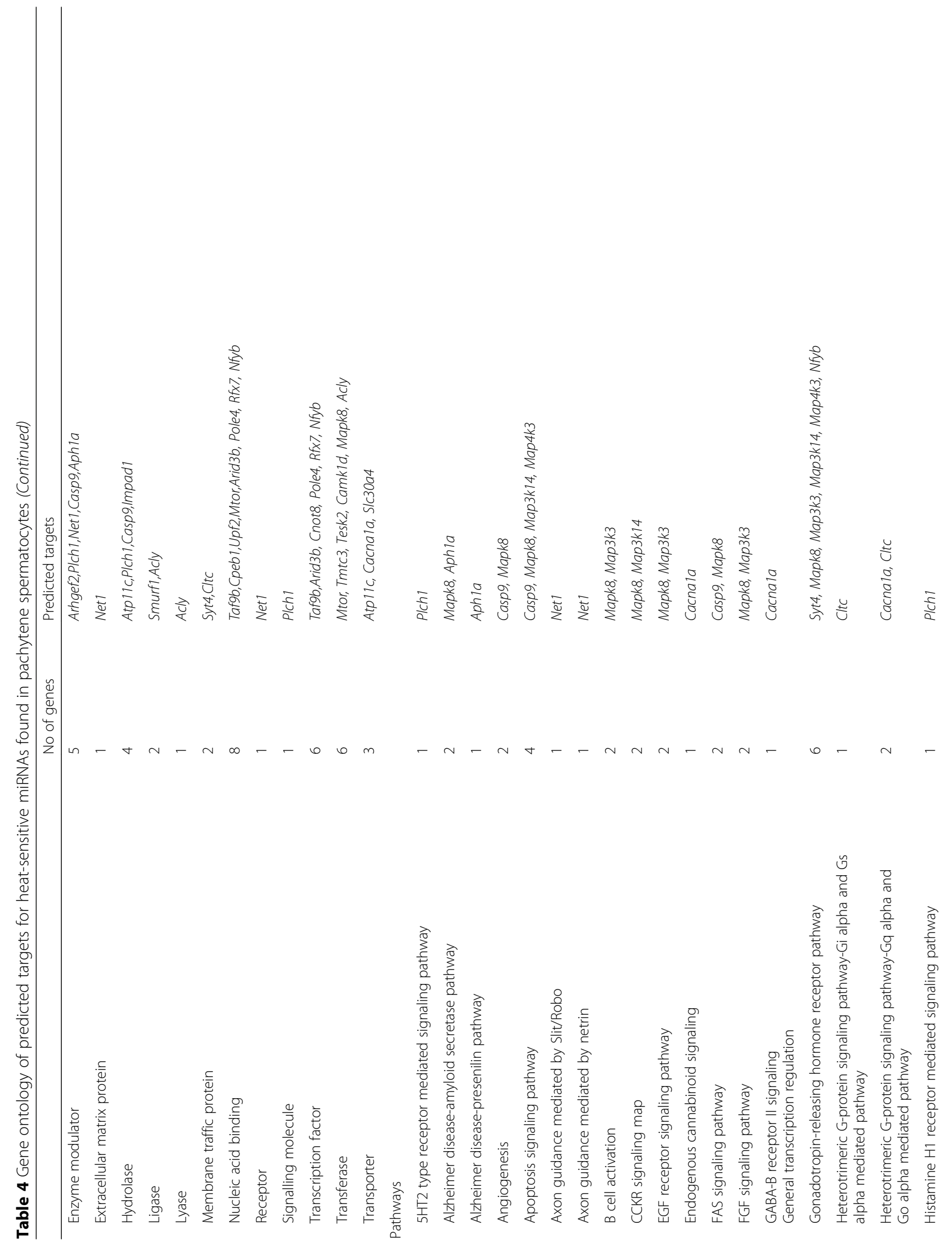




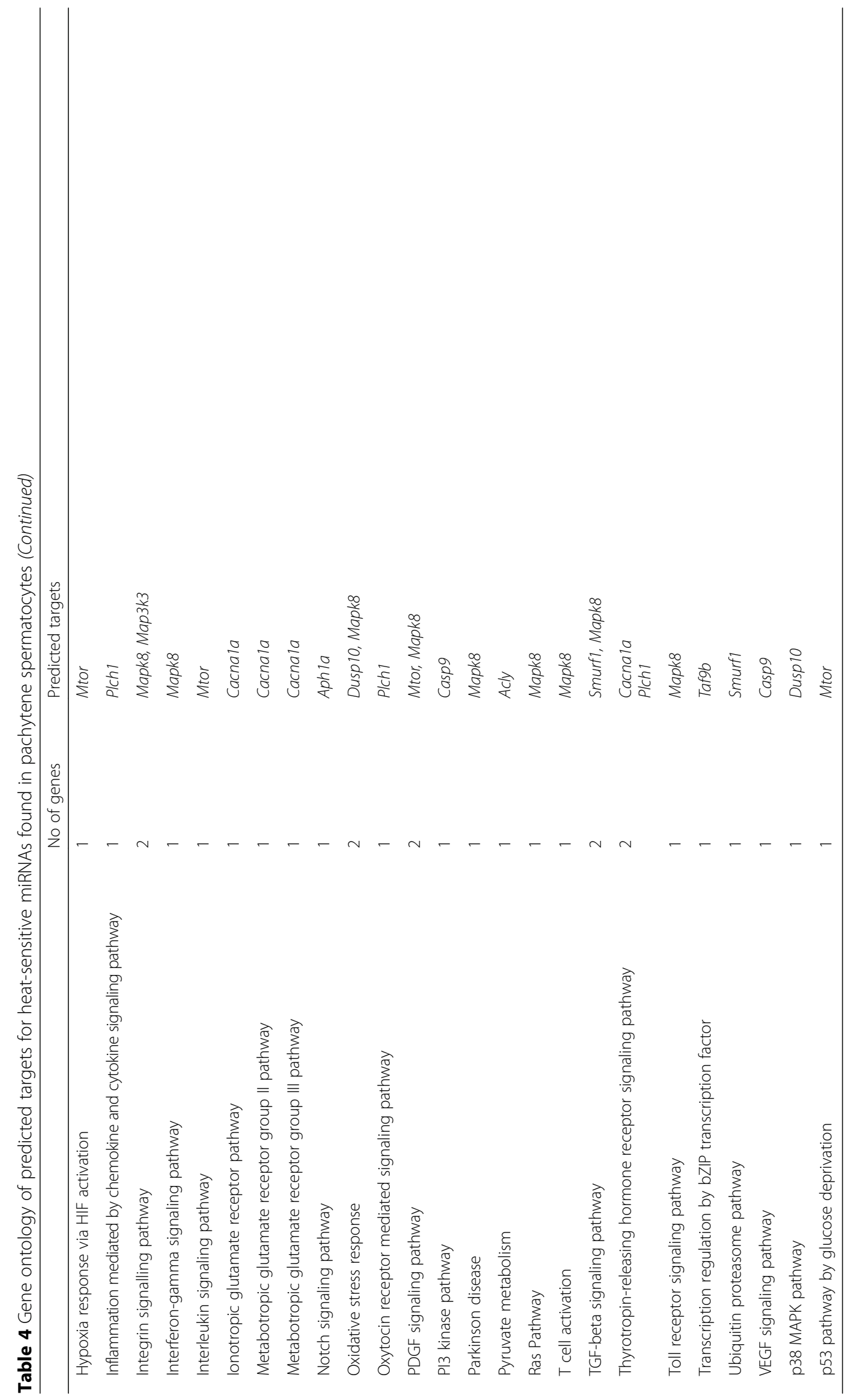




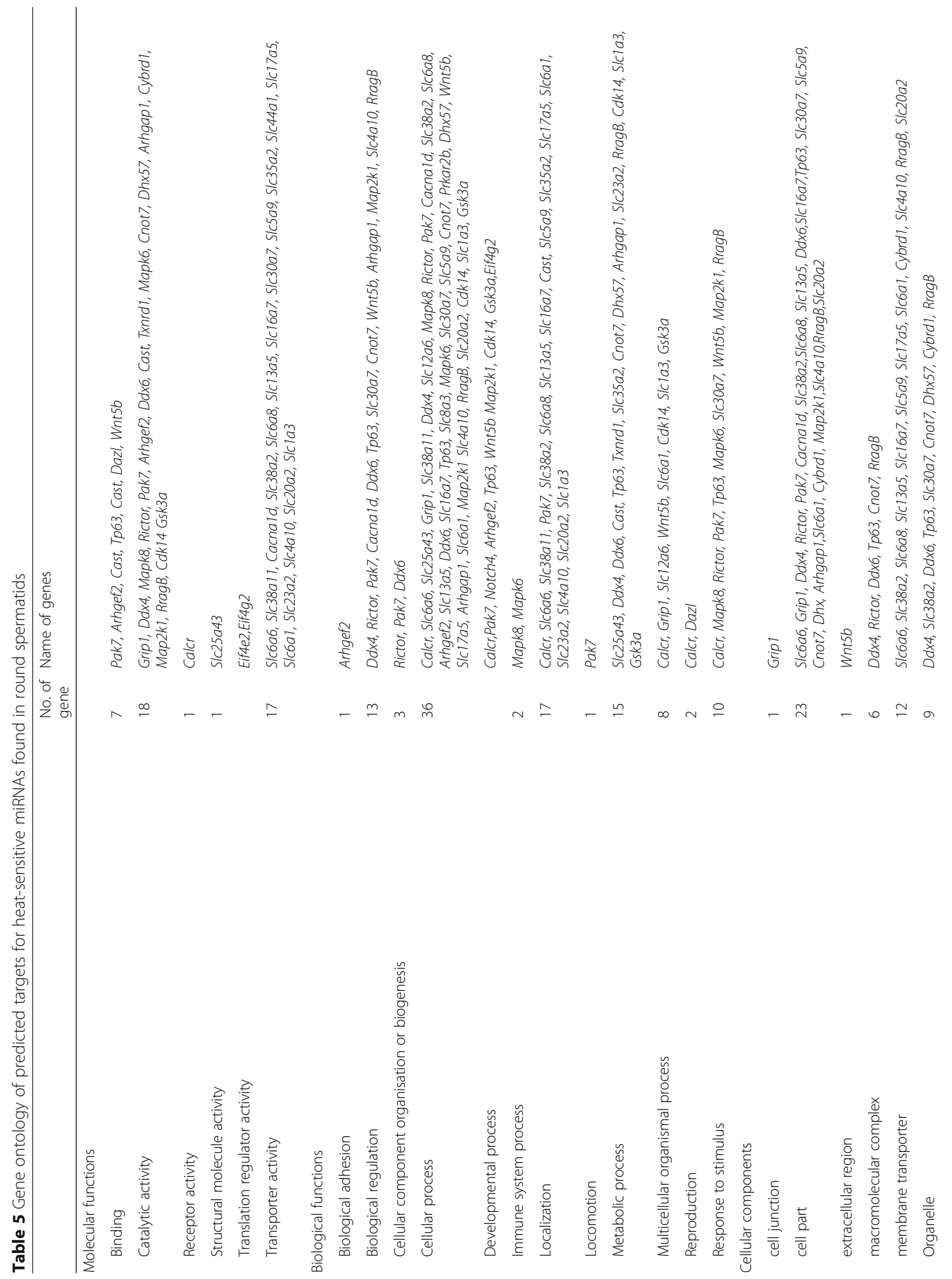




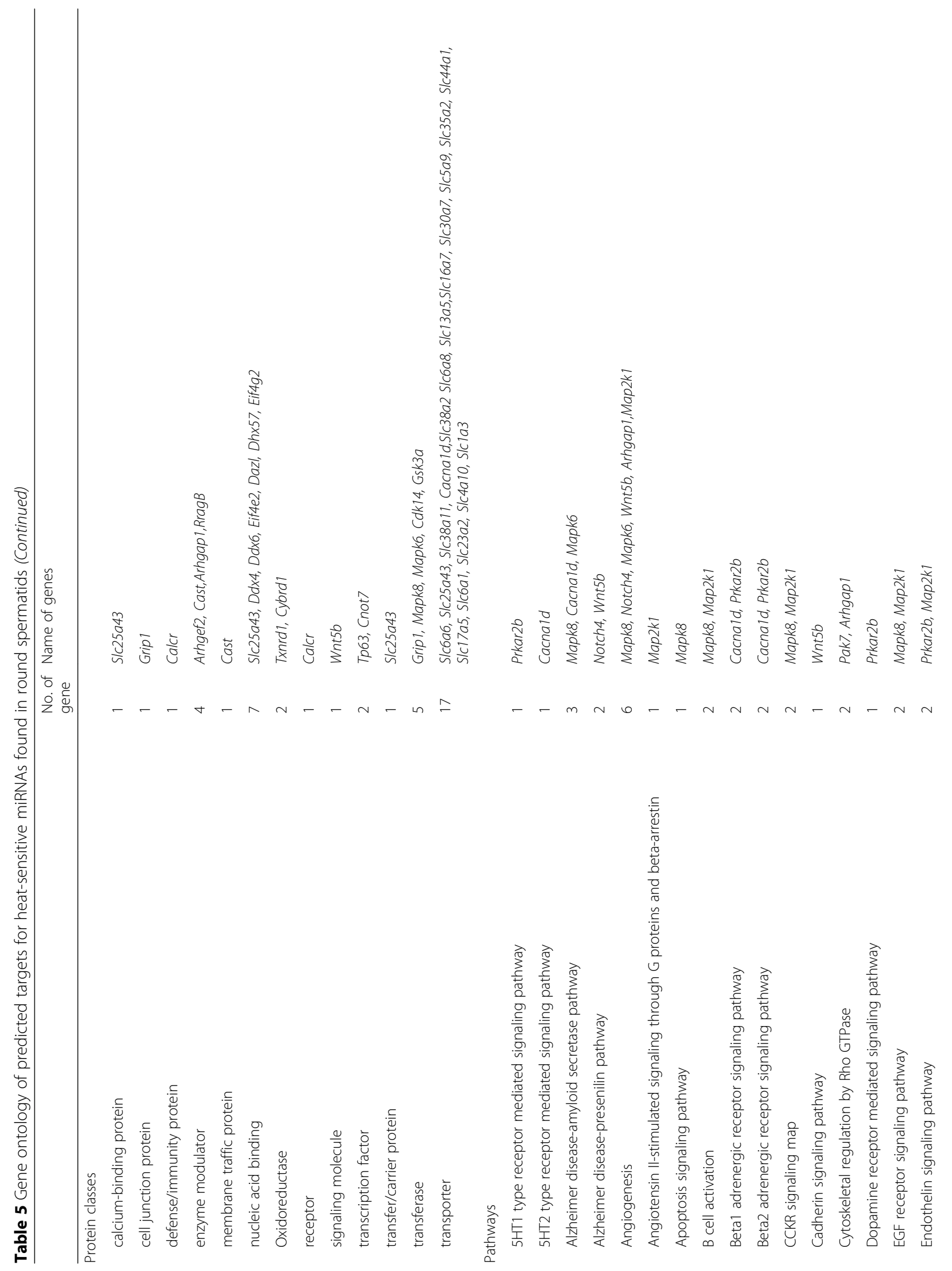




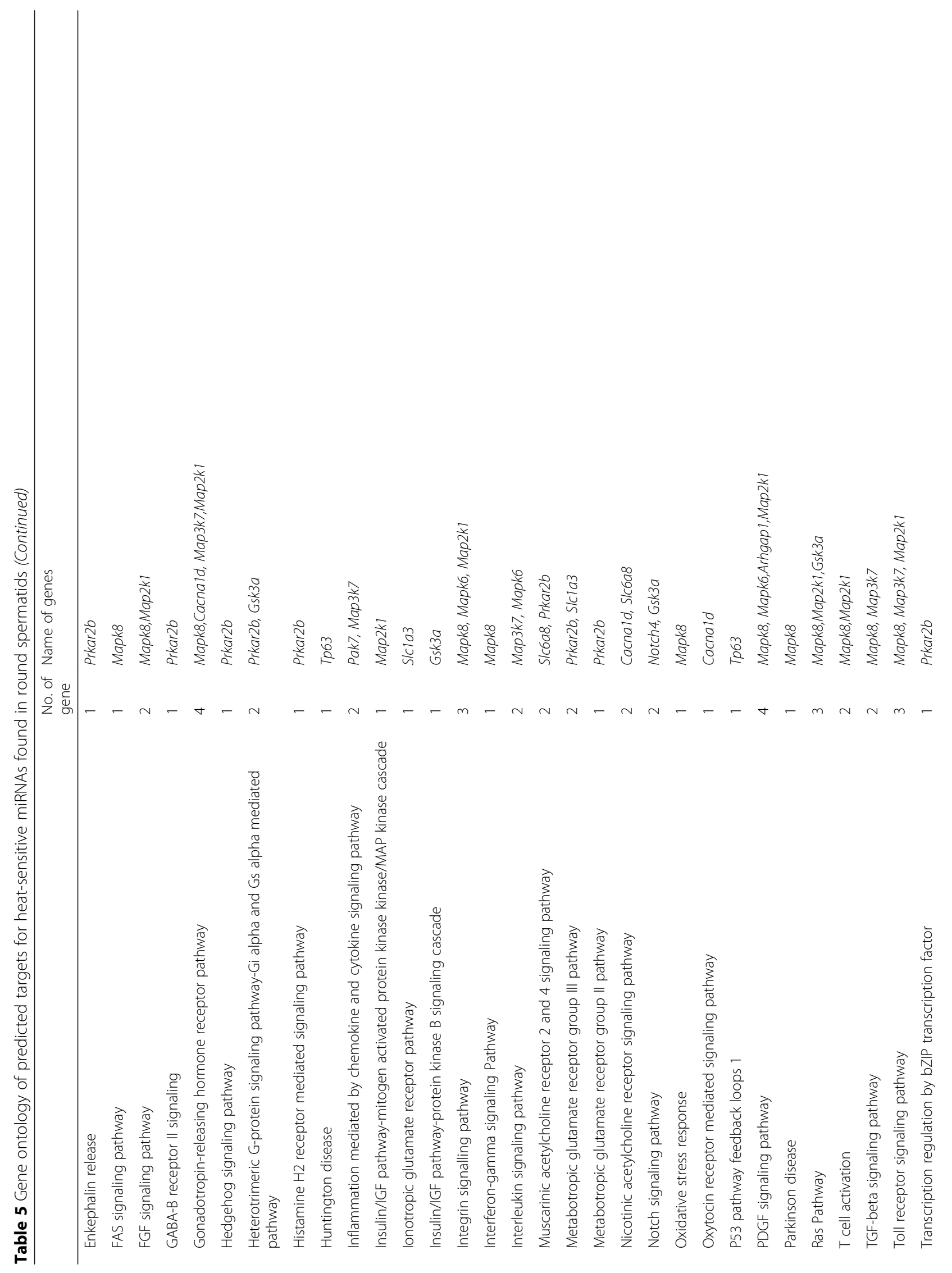




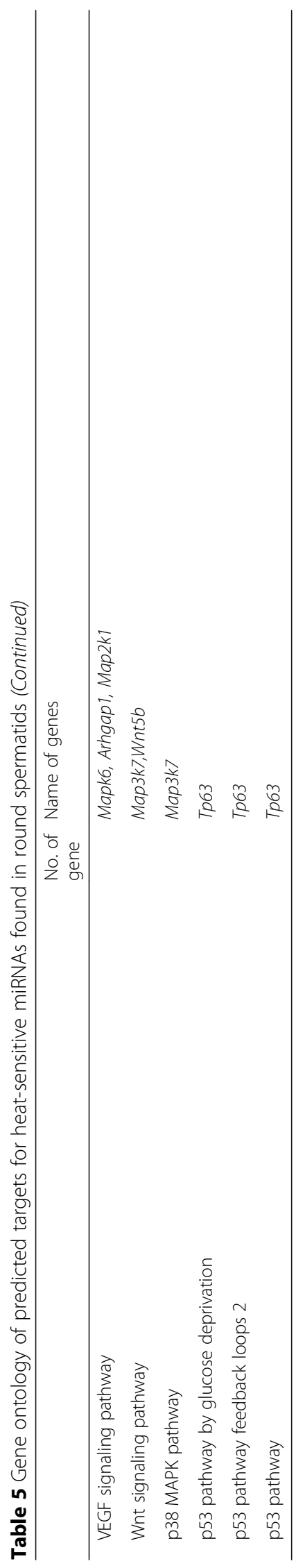


mitochondrial $\mathrm{NADH} / \mathrm{NAD}+$ ratio that maintains the TCA cycle in a repressed state. Thus, ACL enzymatic activity is poised to affect both glucose-dependent lipogenesis and cellular bioenergetics [45].

\section{Conclusions}

In conclusion, transcriptome analysis on the most heat sensitive germ cells in the testis identified a large number of genes that were altered by $\geq 2.0$ fold, out of which 594 genes

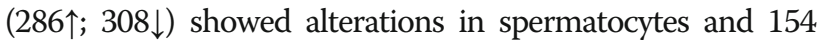
genes $(105 \uparrow ; 49 \downarrow)$ showed alterations in spermatids throughout the duration of experiment. 62 heat-sensitive genes were common to both cell types. Similarly, 66 and 60 heat-sensitive miRNAs in spermatocytes and spermatids, respectively, were affected by $\geq 1.5$ fold, out of which 6 were common to both the cell types. Among various pathways affected significantly by heat stress, the study has identified Acly, selV, SLC16A7(MCT-2), Txnrd1 and Prkar2B as potential heat sensitive targets in germ cells, which may be under tight regulation of heat sensitive miRNAs, rno-miR-22-3P, rno-miR-22-5P, rno-miR-129-5P, rno-miR-3560, rnomiR-3560 and rno-miR-466c-5P, as predicted by miRDB tool. The regulatory targets of these miRNAs, particularly their effect on the top genes altered by heat stress, remain to be worked out. This study has not only advanced our understanding of molecular cues in spermatogenesis but also identified the potential targets for fertility regulation.

\section{Acknowledgments}

The authors gratefully acknowledge the grant of research fellowships by the Council of Scientific and Industrial Research, New Delhi, India (SKY and RV), the Indian Council of Medical Research New Delhi, India (AP) and the Department of Biotechnology New Delhi, India (AD). Thanks are due to the SAIF division for their help in obtaining FACS data.

\section{Funding}

This study was supported by the CSIR-network project BSC0101.

\section{Availability of data and materials}

The datasets supporting the conclusions of this article are included within the article and its files.

\section{Authors' contributions \\ $S K Y, A P, L K, A D, B K$ and RV performed the animal surgeries, cell purification, histology and FACS, gene-expression analysis and all other bench experiments, analysed the data and drafted the manuscript. GG, JPM and SR supervised the experiments, data analysis and bioinformatics. GG and SR conceived the study, designed the experiments and finalized the manuscript. All authors read, edited and approved the final manuscript.}

\section{Ethics approval}

All animal experiments were approved by the Institutional Animal Ethics Committee (IAEC) of CSIR-CDRI, Lucknow.

\section{Competing interests}

The authors declare that they have no competing interests.

\section{Publisher's Note}

Springer Nature remains neutral with regard to jurisdictional claims in published maps and institutional affiliations.
Received: 23 January 2018 Accepted: 22 May 2018

Published online: 02 June 2018

\section{References}

1. Mieusset $R$, Bujan $L$. The potential of mild testicular heating as a safe, effective and reversible contraceptive method for men. Int J Androl. 1994; 17(4):186-91.

2. Fahim MS, Fahim Z, Der R, Hall DG, Harman J. Heat in male contraception (hot water $60{ }^{\circ} \mathrm{C}$, infrared, microwave, and ultrasound). Contraception. 1975; 11(5):549-62.

3. Toppari J, Larsen JC, Christiansen $P$, Giwercman A, Grandjean P, Guillette $\bigsqcup_{\text {, }}$ Jégou B, Jensen TK, Jouannet P, Keiding N, Leffers H, McLachlan JA, Meyer O, Müller J, Rajpert-De Meyts E, Scheike T, Sharpe R, Sumpter J, Skakkebaek NE. Male reproductive health and environmental xenoestrogens. Environ Health Perspect. 1996;104:741-803.

4. Carlsen E, Andersson AM, Petersen JH, Skakkebaek NE. History of febrile illness and variation in semen quality. Hum Reprod. 2003;18:2089-92.

5. Chowdhury AK, Steinberger E. Early changes in the germinal epithelium of rat testes following exposure to heat. J Reprod Fertil. 1970;22:205-12.

6. Lue YH, Hikim AP, Swerdloff RS, Im P, Taing KS, Bui T, Leung A, Wang C. Single exposure to heat induces stage-specific germ cell apoptosis in rats: role of intratesticular testosterone on stage specificity. Endocrinology. 1999; 140:1709-17.

7. Shiraishi $\mathrm{K}$, Matsuyama $\mathrm{H}$, Takihara $\mathrm{H}$. Pathophysiology of varicocele in male infertility in the era of assisted reproductive technology. Int J Urol. 2012;19: 538-50.

8. Steger K. Haploid spermatids exhibit translationally repressed mRNAs. Anat Embryol (Berl). 2001;203(5):323-34.

9. Eddy EM. Male germ cell gene expression. Recent Prog Horm Res. 2002;57: 103-28.

10. Iguchi N, Tobias JW, Hecht NB. Expression profiling reveals meiotic male germ cell mRNAs that are translationally up- and down-regulated. Proc Natl Acad Sci. 2006:103:7712-7.

11. Xiao P, Tang A, Yu Z, Gui Y, Cai Z. Gene expression profile of 2058 spermatogenesis-related genes in mice. Biol Pharm Bull. 2008:31:201-6.

12. Waldman Ben-Asher H, Shahar I, Yitzchak A, Mehr R, Don J. Expression and chromosomal organization of mouse meiotic genes. Mol Reprod Dev. 2010; 77:241-8.

13. Yu Z, Guo R, Ge Y, Ma J, Guan J, Li S, Sun X, Xue S, Han D. Gene expression profiles in different stages of mouse spermatogenic cells. Biol Reprod. 2003; 69:37-47.

14. Geisinger A, Rodríguez-Casuriaga R. Flow cytometry for gene expression studies in mammalian spermatogenesis. Cytogenet Genome Res. 2010;128:46-56.

15. Johnston DS, Wright WW, Dicandeloro P, Wilson E, Kopf GS, Jelinsky SA. Stagespecific gene expression is a fundamental characteristic of rat spermatogenic cells and Sertoli cells. Proc Natl Acad Sci. 2008;10524:8315-20.

16. Schultz N, Hamra FK, Garbers DL. A multitude of genes expressed solely in meiotic or postmeiotic spermatogenic cells offers a myriad of contraceptive targets. Proc Natl Acad Sci. 2003;100:12201-6.

17. Schlecht U, Demougin $P$, Koch R, Hermida L, Wiederkehr C, Descombes $P$, Pineau $C$, Jégou $B$, Primig $M$. Expression profiling of mammalian male meiosis and gametogenesis identifies novel candidate genes for roles in the regulation of fertility. Molec Biol Cell. 2004;15:1031-43.

18. Xu Q, Modrek B, Lee C. Genome-wide detection of tissue-specific alternative splicing in the human transcriptome. Nucleic Acids Res. 2002;30:3754-66.

19. Huang X, Li J, Lu L, Xu M, Xiao J, Yin L, Zhu H, Zhou Z, Sha J. Novel development-related alternative splices in human testis identified by cDNA microarrays. J Androl. 2005;26:189-96.

20. Laiho A, Kotaja N, Gyenesei A, Sironen A. Transcriptome profiling of the murine testis during the first wave of spermatogenesis. PLoS One. 2013;8: e61558.

21. Soumillon $M$, Necsulea $A$, Weier $M$, Brawand $D$, Zhang $X$, Gu H, Barthès $P$, Kokkinaki M, Nef S, Gnirke A, Dym M, de Massy B, Mikkelsen TS, Kaessmann $H$. Cellular source and mechanisms of high transcriptome complexity in the mammalian testis. Cell Rep. 2013:3:2179-90.

22. Margolin G, Khil PP, Kim J, Bellani MA, Camerini-Otero RD. Integrated transcriptome analysis of mouse spermatogenesis. BMC Genomics. 2014;15:39.

23. da Cruz I, Rodríguez-Casuriaga R, Santiñaque FF, Farías J, Curti G, Capoano CA, Folle GA, Benavente R, Sotelo-Silveira JR, Geisinger A. Transcriptome analysis of highly purified mouse spermatogenic cell populations: gene 
expression signatures switch from meiotic-to postmeiotic-related processes at pachytene stage. BMC Genomics. 2016;17:294.

24. Meistrich ML, Longtin J, Brock WA, Grimes SR, Macc ML. Purification of rat spermatogenic cells and preliminary biochemical analysis of these cells. Biol Reprod. 1981;25:1065-77.

25. Vogeli M. Contraception through temporary male sterilization. Lancet. 1956; http://www.puzzlepiece.org/bcontrol/voegeli1956.txt.

26. Lue YH, Sinha Hikim AP, Swerdloff RS, Im P, Taing KS, Bui T, Leung A, Wang C. Single exposure to heat induces stage-specific germ cell apoptosis in rats: role of intratesticular testosterone on stage specificity. Endocrinology. 1999 Apr 1;140(4):1709-17.

27. Reuter K, Schlatt S, Ehmcke J, Wistuba J. Fact or fiction: in vitro spermatogenesis. Spermatogenesis. 2012;2:245-52.

28. Lam DMK, Furrer R, Bruce WR. The separation, physical characterization, and differentiation kinetics of spermatogonial cells of the mouse. Proc Natl Acad Sci. 1970;65:192-9

29. Go VLW, Vernon RG, Fritz IB. Studies on spermatogenesis in rats. I. Application of the sedimentation velocity technique to an investigation of spermatogenesis. Can J Biochem. 1971;49:753-60.

30. Romrell $L$, Bellvé AR, Fawcet DW. Separation of mouse spermatogenic cells by sedimentation velocity. Dev Biol. 1976;19:119-31.

31. Meistrich ML. Separation of spermatogenic cells and nuclei from rodent testes. Methods Cell Biol. 1977;15:15-54.

32. Levy-Rimler G, Viitanen P, Weiss C, Sharkia R, Greenberg A, Niv A, Lustig A, Delarea $Y$, Azem A. The effect of nucleotides and mitochondrial chaperonin 10 on the structure and chaperone activity of mitochondrial chaperonin 60 . Eur J Biochem. 2001;268:3465-72.

33. Yunoki T, Kariya A, Kondo T, Hayashi A, Tabuchi Y. Gene expression analysis of heat shock protein a family members responsive to hyperthermic treatments in normal human fibroblastic cells. Therm Med. 2012;28:73-85.

34. Yoshihisa Y, Hassan MA, Furusawa Y, Tabuchi Y, Kondo T, Shimizu T. Alkannin, HSP70 inducer, protects against UVB-induced apoptosis in human keratinocytes. PLoS One. 2012;7(10):e47903.

35. Boussouar F, Benahmed M. Lactate and energy metabolism in male germ cells. Trends Endocrinol Metab. 2004;15:345-50.

36. Mita M, Hall PF. Metabolism of round spermatids from rats: lactate as the preferred substrate. Biol Reprod. 1982;26:445-55.

37. Goldberg E, Eddy EM, Duan C, Odet F. LDHC the ultimate testis specific gene. J Androl. 2010:31(1):86-94.

38. Odet F, Duan C, Willis WD, Goulding EH, Kung A, Eddy EM, Goldberg E. Expression of the gene for mouse lactate dehydrogenase $C$ (LdhC) is required for male fertility. Biol Reprod. 2008;79(1):26-34.

39. Millan JL, Driscoll CE, LeVan KM, Goldberg E. Epitopes of human testisspecific lactate dehydrogenase deduced from a cDNA sequence. Proc Natl Acad Sci. 1987;84:5311-5

40. Murdoch FE, Goldberg E. Male contraception: another holy grail. Bioorg Med Chem Lett. 2014;24(2):419-24.

41. Kishimoto A, Ishiguro-Oonuma T, Takahashi R, Maekawa M, Toshimori K Watanabe M, Iwanaga T. Immunohistochemical localization of GLUT3, MCT1, and MCT2 in the testes of mice and rats: the use of different energy sources in spermatogenesis. Biomed Res. 2015;36(4):225-34.

42. Galardo MN, Regueira M, Riera MF, Pellizzari EH, Cigorraga SB, Meroni SB. Lactate regulates rat male germ cell function through reactive oxygen species. PLoS One. 2014;9(1):e88024.

43. Lin R, Tao R, Gao X, Li T, Zhou X, Guan KL, Xiong Y, Lei QY. Acetylation stabilizes ATP-citrate lyase to promote lipid biosynthesis and tumor growth. Mol Cell. 2013;51(4):506-18.

44. Migita T, Okabe S, Ikeda K, Igarashi S, Sugawara S, Tomida A, Taguchi R, Soga T, Seimiya H. Inhibition of ATP citrate lyase induces an anticancer effect via reactive oxygen species: AMPK as a predictive biomarker for therapeutic impact. Am J Pathol. 2013:182(5):1800-10.

45. Hatzivassiliou G, Zhao F, Bauer DE, Andreadis C, Shaw AN, Dhanak D, Hingorani SR, Tuveson DA, Thompson CB. ATP citrate lyase inhibition can suppress tumor cell growth. Cancer Cell. 2005;8(4):311-21.

\section{Ready to submit your research? Choose BMC and benefit from:}

- fast, convenient online submission

- thorough peer review by experienced researchers in your field

- rapid publication on acceptance

- support for research data, including large and complex data types

- gold Open Access which fosters wider collaboration and increased citations

- maximum visibility for your research: over $100 \mathrm{M}$ website views per year

At BMC, research is always in progress.

Learn more biomedcentral.com/submissions 